\title{
Survey of Historical and \\ Current Site Selection \\ Techniques for the Placement \\ of Small Wind Energy \\ Conversion Systems
}

December 1977

Prepared for

Pacific Northwest Laboratory

under Agreement No. B-3602-A-E

Pacific Northwest Laboratory

Richland, Washington 99352

Operated for the

U.S. Department of Energy

by 
NOTICE

This report was prepared as an account of work sponsored by the United States Government. Neither the United States nor the Department of Energy, nor any of their employees, nor any oi their contractors, subcontractors, or their employees, makes any warranty, express or implied, or assumes any legal liability or responsibility for the accuracy, completeness or usefulness of any information, apparatus, product or process disclosed, or represents that its use would not infringe privately owned rights.

The views, opinions and conclusions contained in this report are those of the contractor and do not necessarily represent those of the United States Government or the United States Department of Energy.

\author{
PACIFIC NORTHWEST LABORATORY \\ operated by \\ BATTELLE \\ for the \\ UNITED STATES DEP.ARTMENT OF ENERGY \\ Under Contract EY-76-C-06-7830
}

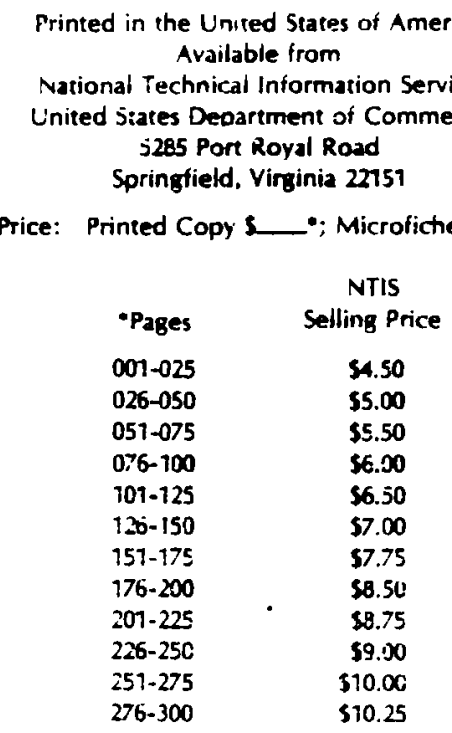


BNWL-2220-

WIND-9

UC-60

SURVEY OF HISTORICAL AND CURRENT SITE
SELECTION TECHNIQUES FOR THE PLACEMENT
OF SMALL WIND ENERGY CONVERSION SYSTEMS

American Wind Energy Association

$c / 0$ Windworks

P. 0. Box 329 , Route 3

Mukwonago, WI 53149

PREPARED FOR

PACIFIC NORTHWEST LABORATORY

UNDER AGREEMENT NO. B-3602-A-E

December 1977

PACIFIC NORTHWEST LABORATORY

RICHLAND, WASHINGTON 99352

OPERATED BY

BATTELLE MEMORIAL INSTITUTE 


\section{FOREWORD}

This report was prepared for Battelle, Pacific Northwest Laboratory (PNL) as part of Special Agreement B-36302-A-E betweon PNL and the American Wind Energy Association (AWEA). The objective of the work was to provide PNL with background information on historical practices in siting small wind energy conversion systems. The information in the report describes the approach taken by AWEA and presents conclusions and recommendations based upon their experience.

PNL intends to combine the conclusions and recommendations presented by AWEA with results of its own analysis of the data for use as input in planning for the Wind Characteristics Program Element of the Federal Wind Energy Program.

The efforts and cooperation of the offices and members of AWEA who contributed to this work are greatly appreciated.

J. V. Ramsde 11

Contract Technical Monitor

Battelle, Pacific Northwest Laboratory 


\section{CONTENTS}

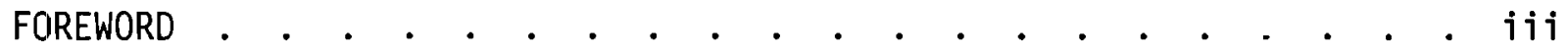

1. INTRODUCTION . . . . . . . . . . . . . . . . . . . . . 1

2. CONCLUSIONS AND RECOMMENDATIONS . . . . . . . . . . . . . . 1

3. APPROACH . . . . . . . . . . . . . . . . . . 2

4. DISCUSSION . . . . . . . . . . . . . . . . . . . 5

4.1 Siting WECS for Pumping Water . . . . . . . . . . 6

4.2 Siting WECS for Generating Electricity . . . . . . . 7

4.3 Current WECS Siting Guidelines . . . . . . . . . . 7

4.4 Future Siting Guidelines . . . . . . . . . . . . 9

5. PRINCIPAL FINDINGS . . . . . . . . . . . . . . . . 10

6. REFERENCES . . . . . . . . . . . . . . . . . . . . . 11

APPENDIX A - LIST OF NEWSPAPERS CARRYING SITING STUDY ADS . . . . . 13

APPENDIX B - SAMPLE QUESTIONNAIRE AND RESPCNSES . . . . . . . . . 19

APPENDIX C - PAST AND PRESENT WECS DISTRIBUTORS . . . . . . . . . 28

APPENDIX D - SITING GUIDELINES . . . . . . . . . . . . . . . . . 31

APPENDIX E - WIND ENERGY BIBLIOGRAPHY . . . . . . . . . . . . 44

ACKNOWLEDGMENT . . . . . . . . . . . . . . . . . . . . 71 


\section{INTRODUCTION}

Individuals and groups who purchase and install wind energy conversion systems (WECS) for either generation of electricity or pumping water have to go through a process by which a specific location is selected for each wECS. The purpose of this study was to identify and document methods and practices used in siting of WECS. The study covers the period from the early 1900 s to the present day.

The process of WECS siting is not exclusively a meteorological concern, but represents a balance between the economic and technical considerations and social values of the user. Site selection can be a critical factor in determining the economic viability of a given wind system installation. This is demonstrated by the Smith-Putnam experimental wind turbine built in Vermont in 1941. The mean wind speed at the site was over-estimated to such an extent that the energy obtained was on $1 y 1 / 3$ the expected value. (1) The economics of today's numerous energy sources are highly competitive unlike the historical applications of wind energy.

Tools employed in the siting process to carefully assess a given wind installation are evolving as a more complex technology than previously employed. This is in part due to an increased understanding of the variables involved in siting and recognition of the need to quantify the intuitive understanding gained in thousands of past WECS installations.

The systematic development of siting technology in part, requires an understanding of historical siting practices.

\section{CONCLUSIONS AND RECOMMENDATIONS}

AWEA concludes that:

- WECS in general were used where there was an intuitively understood "minimal availability" of wind energy.

- Water pumping systems were sited on the basis of availability of water.

- Electric generating systems were sited on the basis of rough "rules of thumb," generally a minimum height above obstacles within a specified radius. 
- Current distributors of WECS are using these historical "rules of thumb" in addition to inexpensive anemometry and simplified data reduction techniques.

- Current distributors are inclined to take advantage of advances in siting hardware and techniques.

AWEA recommends that:

- A program be developed that more fully disperses recent developments in WECS siting to the end user. Elements of this program could include:

- WECS dealer siting seminars

- Extension agent siting seminars

- Siting handbooks

- Presentation of existing wind data in a form appropriate for use by non-technical user groups.

- A program be developed that assesses all present siting techniques in terms of WECS applications. These applications vary in relation to:

- WECS size

- End power use

- Accuracy required

- Topography

\section{APPROACH}

Since siting procedures ultimately relate to the sale of a wind machine, answers to questions such as:

- How were wind machines sold?

- How were wind machines sited?

- How were wind machines installed?

- What was the correlation between sales statements made from siting studies and the actual experience after installation? (How accurate were performance predictions?)

offer insight into the technology used. This study has been conducted to collect and compile information which will provide answers to these and other siting related questions. 
The American Wind Energy Association (AWEA) conducted the study through questionnaires, interviews and a literature search. Ads seeking sources of information on WECS siting were placed in local newspapers in geographic regions where WECS were widely used. (See Appendix A for a list of papers in which ads were placed.) Respondeec were mailed an interview questionnaire. A total of 600 questionnaires were mailed out and 175 were returned. The return rate for this portion was $29 \%$. A total of 158 returned questionnaires were validated using data on ownership of WECS. Those questionnaires not validated were returned by interested parties who had not owned a WECS. The questionnaire used is presented in Appendix B. Responses to the questions are tabulated in the Appendix by both number and as a percentage of total responses.

Personal interviews were conducted in the west, midwest, and mountain regions of known past high populations of WECS to gain additional information. Institutional buyers of old WECS were contacted to identify areas in which they found machines, and where possible to identify specific past owners. Where wind machine towers were seen while driving, a stop was made and an interview was attempted. Generally, it was found that present owners of WECS insta11ations are two, sometimes three owners removed from the original owner. Interviews were found to be time consuming, but of ten very valuable. This was particularly true when past dealers of WECS and ranchers with large numbers of WECS were willing to discuss their experiences.

Many prime resources for interviews and discussions of past techniques have recently passed away, and literature on the specific subject of historical WECS siting techniques was not extensive. Thus, the personal interviews have been important. It is surmised that this study, if conducted a few years hence, would have yielded little direct data.

Interviews were also conducted with academic and institutional researchers currently involved with atmospheric sciences and siting technolcgy. It is clear that correlations exist between past and present thinking.

Siting information was sought from past and present distributors of WECS. Appendix $C$ presents a list of the distributors contacted. In addition, Figure 1 shows the regions of the U.S. which were covered by the survey and by the AWEA team in its travels. 


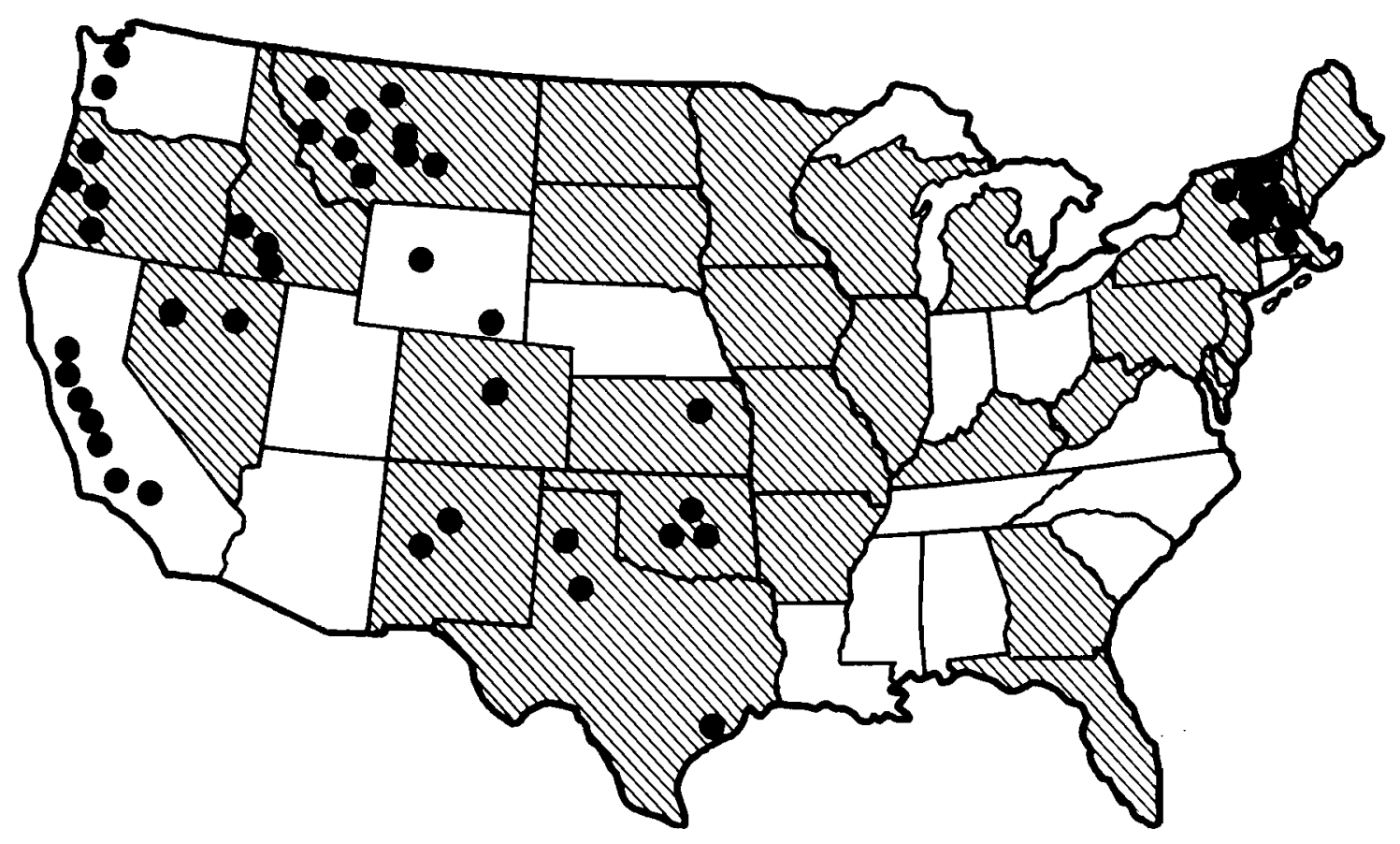

STATES FROI I:JHICH RESPONSES TO QUESTIONNAIRES WERE RECEIVED

POIIITS VISITED

FIGURE 1. Regions of the U.S. Covered by the Siting Survey and the AWEA Travels 
The literature review, while not finding a great deal of information explicitly on WECS siting, did identify siting guidelines offered by WECS manufacturers. Excerpts from these guidelines are contained in Appendix D. A listing of the literature related to wind energy, wind energy conversion and wind energy conversion systems which was reviewed is presented in Appendix E. In the Appendix, the listings of significant papers and reports have been annotated.

\section{DISCUSSION}

Extensive analysis of the results of the questionnaire has not been attempted, nor was it a part of the current study. The discussion which follows is based primarily upon responses to individual questions in the questionnaire as tabulated in Appendix $B$, and information gained during interviews and from the literature related to WECS siting.

The number of WECS represented in this study is 2,326 . This includes responses from two ranches with over 1,000 water pumpers each. Not considering these two large groups of water pumpers, the percentage of WECS used for water pumping is $95 \%$, the remaining $5 \%$ are for generating electricity. We feel this approximates the distribution of machines currently in use.

Table 1 illustrates the breakdown of data collected relative, essentially, to application and time of installation. It is felt that for relative application comparison, it is reasonable to synthesize the figure without the large water pumper users as these machines were less affected by the Rural Electrification Administration (REA). REA installed lines to the houses which used WECS, but not to the fields which used water pumpers. Some 500,000 wind electric systems are known to have been built, but most fell into disuse because of the REA.

WECS covered in the study were installed prior to 1961 and after 1970, as shown in Table 1. Prior to this break, the majority of the WECS installed were for water pumping, while since the break the majority have been electrical generating systems. The decreasing number of installations from the 1936-1940 period to the 1946-1950 period, and the few installations from 1951-1970 indicate the decreasing interest in utilization in wind energy conversion. The 
TABLE 1. Dates of Installations

\begin{tabular}{lcc} 
Period & Mechanical & Electrical \\
\cline { 2 - 3 } prior to 1910 & 97 & 0 \\
$1910-1915$ & 3 & 1 \\
$1916-1920$ & 4 & 1 \\
$1921-1925$ & 3 & 1 \\
$1926-1930$ & 7 & 1 \\
$1931-1935$ & 2 & 4 \\
$1936-1940$ & 87 & 4 \\
$1941-1945$ & 26 & 7 \\
$1946-1950$ & 2 & 4 \\
$1951-1955$ & 0 & 1 \\
$1956-1960$ & 0 & 2 \\
$1961-1965$ & 0 & 0 \\
$1966-1970$ & 0 & 0 \\
$1971-1975$ & 1 & 27 \\
$1976-$ present & 0 & 12 \\
& 232 & 65
\end{tabular}

(This chart does not include users who had over 1,000 machines each.)

Total number of machines represented in the study: 2,236

$$
\text { water pumpers: } 95 \% \text { electrical: } 5 \%
$$

Total number of questionnaires mailed: 600

Total number of questionnaires returned: $\frac{\text { Total }}{175} \frac{\text { Validated }}{158}$

Return rate: $\quad 29 \% \quad 26 \%$

WECS installations since 1970 indicate the resurgence in interest. The shift in type of WECS installed from mechanical water pumping to electrical generation reflects a renewed interest in electrical generation, although the actual ratio of new WECS installations may not be as one-sided as the Table indicates.

\subsection{Siting WECS for Pumping Water}

The siting of water pumping WECS was straightforward, governed primarily by the availability of water. The typical tower height for these machines was $30 \mathrm{ft}$, with higher towers used primarily when the machine was located in 
a.draw. Water pumping machines are still widely used for supplying range water. The marketing system, within specific geographic areas, is well established. There are a number of small companies ( 3 to 5 emp?oyees) in the Southwest and Plains states that install and maintain these machines on a full-time basis.

There is no indication from the questionnaires received or the interviews conducted that the present distributors or users of wind machines for pumping water would be willing to invest a significant amount of time or money in siting surveys. This is perhaps a result of the experience gained with the machines currently in use. It also reflects the fact that most machines are installed in regions of demonstrated wind energy potential.

\subsection{Siting WECS for Generating Electricity}

The siting of WECS for generating electricity incorporated much of the experience of long time dealers of water pumping machines. Still guided by intuitive feelings and "rules of thumb," rather than data collection and reduction, siting guidelines were described in owner's manuals.

Generally in the sale of electrical generation systems, no representations were made about specific performance. While manufacturers claimed performance (e.g., $500 \mathrm{kWh} / \mathrm{mo}$ for Model X), dealers sold the machines on experience gained locally. Dealers sold a WECS to charge a given number of batteries, or to power a certain number of lights. No claims were made regarding actual energy production.

Response to question 3 of the siting questionnaire indicates that in the past WECS for electrical generation were expected to provide power primarily for radios and home appliances using batteries as the storage medium. Most of these systems were installed by the owner on a tower with a height of 30 to $50 \mathrm{ft}$ (see Questions 6 and 7, Appendix B). From question 18 it was found that a majority of the respondents (73\%) were satisfied with the operation of their system, in that it provided as much power as was expected previous to installation.

\subsection{Current WECS Siting Guidelines}

As stated before, manufacturers of WECS generally offer some form of siting guidelines. Table 2 summarizes the siting recommendations of eight 


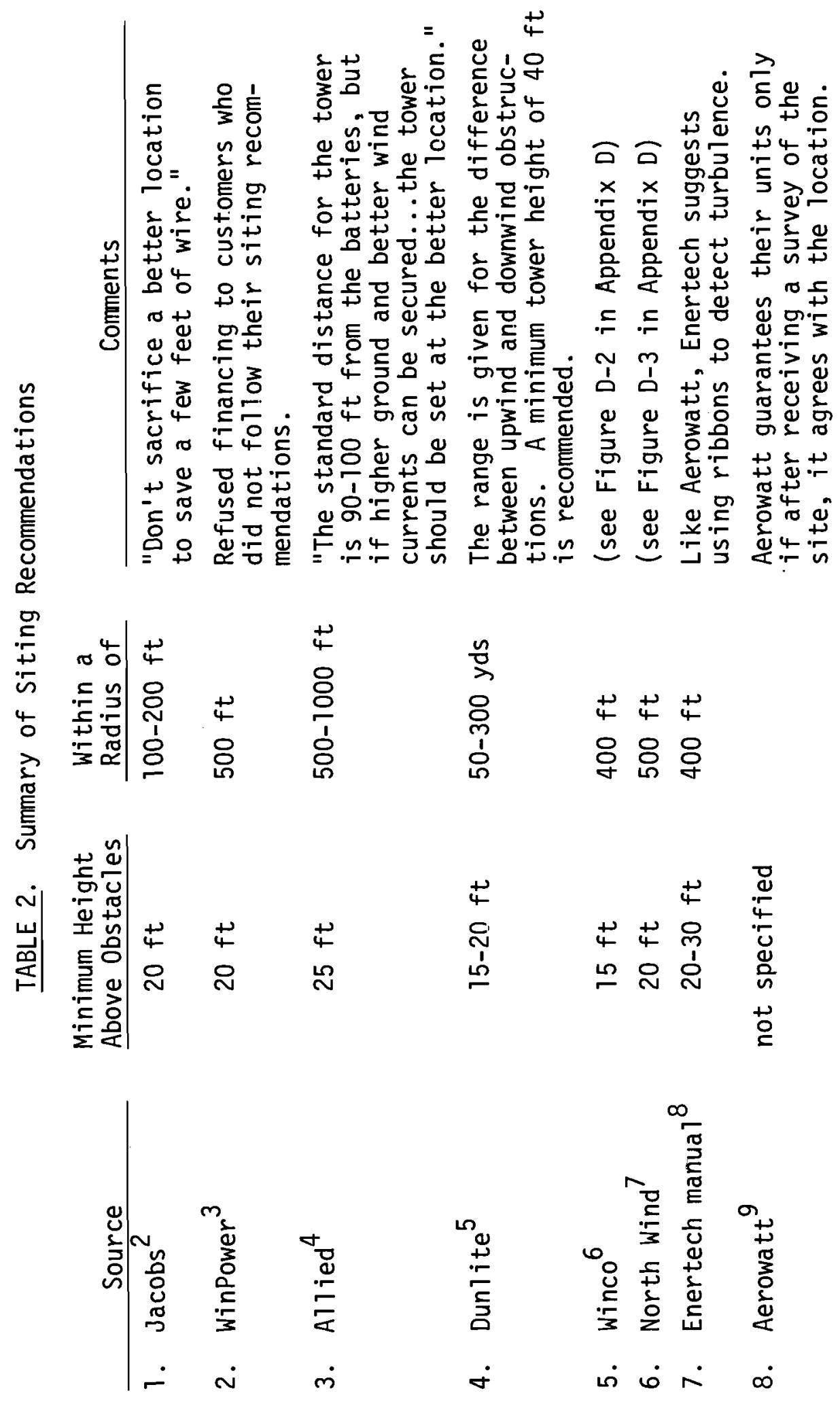


past and present WECS manufacturers and distributors. The complete set of guidelines from which the summary was drawn is contained in Appendix $D$. The siting guidelines generally recommend that WECS be installed $20 \mathrm{ft}$ or more above obstacles within a radius of 300 to $500 \mathrm{ft}$.

\subsection{Future Siting Guidelines}

As the capital investment required for WECS increases, selecting the proper installation site and evaluating the probable output become increasingly important. Approximately $60 \%$ of those individuals answering question 9 of the questionnaire indicated that they knew the wind speed in their area. However, the knowledge of annual average wind speeds in a given area was either nonexistent (approximately $75 \%$ of the questionnaires returned) or grossly overestimated. For example, a number of people estimated their annual average wind speed to be $25 \mathrm{mph}$, while according to National Weather Service Data, the annual average was actually 11 to $12 \mathrm{mph}$ for their area.

The responses to questions 20 and 24 provide a guide to the thoughts of potential WECS users about the siting expenses they are willing to accept. These responses are shown in Table 3 . It should be noted that expenses to determine available wind power are more acceptable than those to determine the best location for WECS installation. Specifical1y, 31\% of the respondents to question 20 would be willing to spend more than $\$ 250$ to determine wind power availability, while only $3 \%$ of those responding to question 24 would be willing to spend that much for determining the best location. However, Table 3 shows that $57 \%$ of the respondents to question 24 would spend more than $\$ 10$ to determine the best locations. This indicates that simple guidelines on selecting the best location would be used.

The responses to questions 22 and 23 indicate that the farm machinery or WECS dealer is the individual most likely to be consulted in selection of a specific location for WECS, while the National Weather Service is most likely to be consulted for information of wind in the area.

By way of contrast, it should be noted that some respondents to the questionnaire answered only the questions they thought applied to their case. In some of these cases, they felt no need for future siting work, perhaps due 
TABLE 3. Responses to Questions Relating to Acceptable Siting Expenses to Determine Wind Power Availability at a Farm and to Identify the Best Location for a WECS Installation on a Farm

\begin{tabular}{ccc} 
Siting Expense & $\begin{array}{c}\text { Power at } \\
\text { Farm }\end{array}$ & $\begin{array}{c}\text { Best Site } \\
\text { on Farm }\end{array}$ \\
\cline { 2 - 2 }$<\$ 10$ & $27 \%$ & $43 \%$ \\
$11-50$ & 22 & 37 \\
$51-100$ & 10 & 9 \\
$100-250$ & 3 & 8 \\
$250-500$ & 31 & 2 \\
$>500$ & 6 & 1
\end{tabular}

to success they had had with a WECS installation. From a topographic standpoint, the respondents ' conclusions may be reasonable, especially when one considers many of these installations were in flat regions of known high annual average winds.

\section{PRINCIPAL FINDINGS}

The primary findings of this study follow:

- The primary factor in selecting the location for a WECS on a given site was the application of the power. Water pumping machines are constrained by the availability of water, and electric generating machines constrained by the location of the batteries. This was amplified by the fact that most wind electric systems prior to 1945 were low voltage (32 vdc), high amperage machines requiring heavy gauge wire.

- When meteorological factors affected the selection of machine location or tower height, such factors were dealt with on a basis of intuitive understanding gained from years of experience, as well as general guidelines supplied by WECS manufacturers.

- With the location of the machine determined by the application of the power, the next factor in the siting process was the selection of tower height. System distributors indicate that tower height decisions were 
often made on the basis of tower cost, while machine owners indicate that tower height was selected to clear obstructions.

- In the application of wind energy to pumping water, some issues that affected site selection and tower height were non-meteorological. Among these were the fact that the tower was used to facilitate the drilling and casing process, and in the presence of abundant water, the WECS were moved to sites the rancher or farmer wanted grazed.

- The widely applied rule of thumb for selecting tower height was that the tower be 15 to $25 \mathrm{ft}$ above obstructions within a 300 to $500 \mathrm{ft}$ radius. The owner's manuals of the period state that dissatisfaction with performance is primarily the result of improper siting.

- While approximately $95 \%$ of those responding used wind machines for water pumping, nearly $75 \%$ of those responding indicated they would like to use wind energy for electrical applications in the future.

- The most often cited source of information on site selection was the WECS salesman or dealer $(53 \%)$.

- Questionnaire responses most often cited the National Weather Service (NWS) (35\%) as the source of information on wind data they would use. It is unclear if those responding to the questionnaire know how to get data from NWS, what type of data to request, or what to do with it once obtained.

- Current dealers are using low cost wind-run, and recording anemometers to assist in site selection.

\section{REFERENCES}

1. P.C. Putnam, Power From the Wind, Van Nostrand, NY, 1948.

2. Jacobs Owner's Manual. Available from North Wind Power Co., Warren, VT.

3. WinPower Owner's Manual. Available from the American Wind Energy Association (AWEA), Bristol, IN.

4. Allied Owner's Manual. Available from the AWEA. 
5. Dunlite Owner's Manual. Available from Enertech, Inc., Norwich, VT.

6. Winco Owner's Manual. Available from Winco, Minneapolis, MN.

7. North Wind Catalogue. Available from North Wind Power Co.

8. Enertech Manual. Available from Enertech, Inc.

9. Aerowatt Owner's Manual. Available from Pennwalt Corp., Houston, TX. 


\section{APPENDIX A}

\section{LIST OF NEWSPAPERS CARRYING SITING STUDY ADS}

Advertisements were placed in local newspapers in geographic regions where WECS were widely used. The purpose was to seek sources of information on siting techniques used. The following newspapers carried the siting study advertisements. 


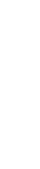


Eastern and Central Time Zones

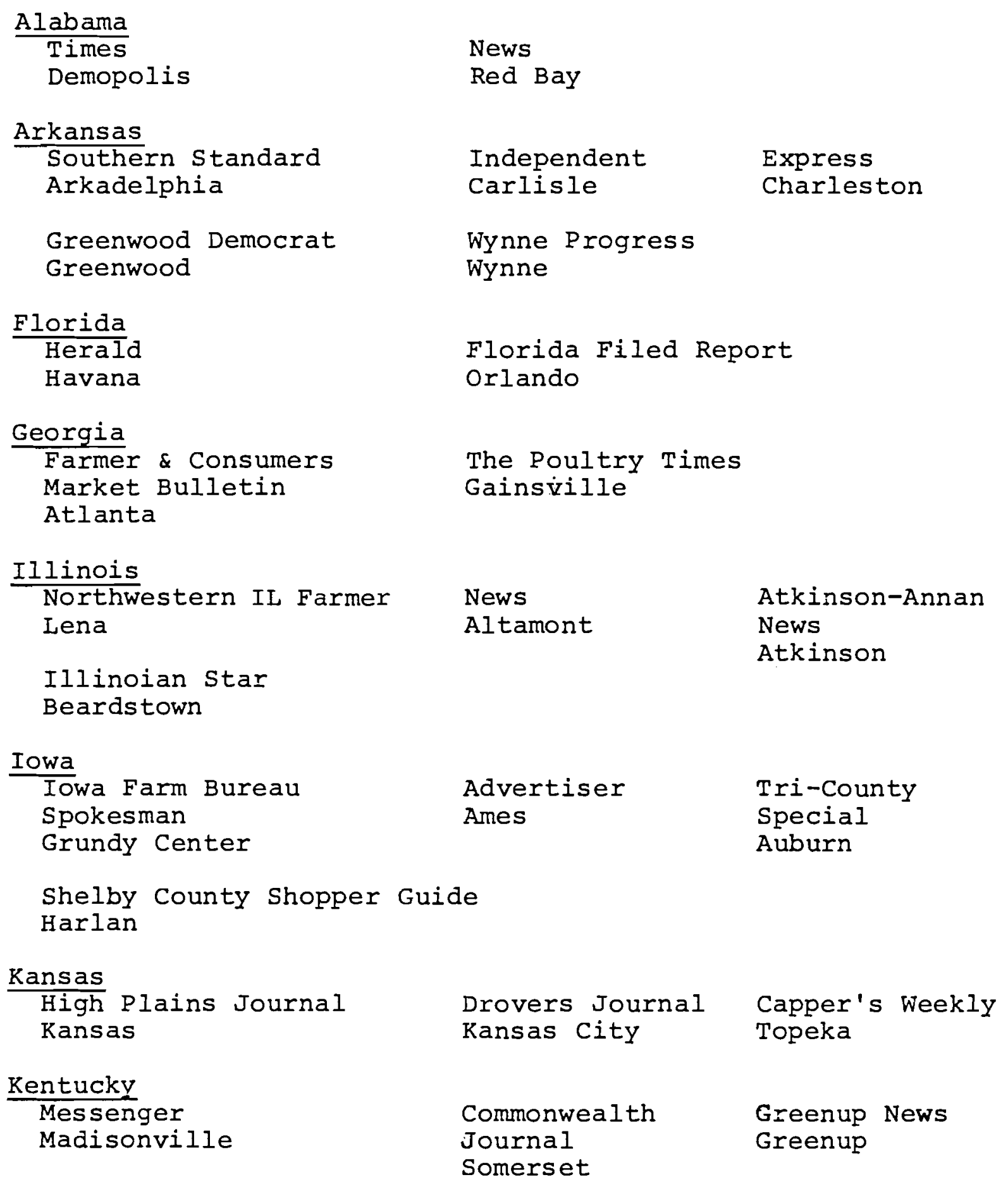


Louisiana

Star PIus

Hammond

Maine

Coastal Journal

Bath

Maryland

Queene Anne's Record-

Observer, Centerville

Massachusetts

Christian Science Moniter Boston

Michigan

Holland Flashes

Allegan

Review

Richmond

Minnesota

Norman County Index Ada

Iivewire

Jackson

Mississippi

Moniter-Herald

Calhoun City

Missouri

Belton-Granview Shopper

Belton

St. Clair County Courier Osceola
Point Coupee Banner

New Roads

Franklin Journal \& Farmington

Chronicle, Farmington

News and Farmer

Preston

The Cape Codder

Orleans

South Shore News Rockland

Shopper Guide

Caro

Courier

Charlevoix

Farmers Advance

Camden

Sentinel

Scotsman

Bricelyn

Cambridge

Sentinel

Tribune

Truman

Delta Farm Press Itawamba county

Clarksdale

Journal of Livestock \& Agricultural

Saint Joseph

Nebraska Journal

Crofton

Livestock Market Digest

Norfolk
Buchanan Co. Farmer and Grower

Gaxette, Faucett

Free Press

Troy 


\begin{tabular}{|c|c|c|}
\hline $\begin{array}{l}\text { Shopper News } \\
\text { Keene }\end{array}$ & $\begin{array}{l}\text { Citizen Publishing } \\
\text { Laconia }\end{array}$ & \\
\hline \\
\hline $\begin{array}{l}\text { R\&L Suburban News } \\
\text { Franklin News }\end{array}$ & $\begin{array}{l}\text { Advertiser } \\
\text { Franklinville }\end{array}$ & $\begin{array}{l}\text { Colonial News } \\
\text { Freehold }\end{array}$ \\
\hline \multicolumn{3}{|l|}{ New York } \\
\hline $\begin{array}{l}\text { Jefferson County Journal } \\
\text { Adams }\end{array}$ & $\begin{array}{l}\text { Albion-Holly } \\
\text { Pennysaver } \\
\text { Albion }\end{array}$ & $\begin{array}{l}\text { Advertiser } \\
\text { Alden }\end{array}$ \\
\hline $\begin{array}{ll}\text { Dairy } & \text { News } \\
\text { Pearl River }\end{array}$ & $\begin{array}{l}\text { Ballston Journal } \\
\text { Ballston }\end{array}$ & $\begin{array}{l}\text { Moneysaver } \\
\text { Shoppers Guide } \\
\text { Bolivar }\end{array}$ \\
\hline \multicolumn{3}{|l|}{ North Carolina } \\
\hline $\begin{array}{l}\text { Village Advocate } \\
\text { Chapel Hill }\end{array}$ & $\begin{array}{l}\text { Southeastern Times } \\
\text { Clarkton }\end{array}$ & $\begin{array}{l}\text { Courier } \\
\text { Clemmons }\end{array}$ \\
\hline \multicolumn{3}{|l|}{$\begin{array}{l}\text { Herald \& Ruralite } \\
\text { Sylva }\end{array}$} \\
\hline \multicolumn{3}{|l|}{ North Dakota } \\
\hline Advertiser & Dicky County Leader & Teller \\
\hline Dickenson & Ellendale & Milnor \\
\hline The Forum & News & \\
\hline fargo & Minot & \\
\hline \multicolumn{3}{|l|}{ Ohio } \\
\hline $\begin{array}{l}\text { Farmland News } \\
\text { Archbold }\end{array}$ & $\begin{array}{l}\text { Firelands Farmer } \\
\text { New London }\end{array}$ & $\begin{array}{l}\text { Farm and Dairy } \\
\text { Salem }\end{array}$ \\
\hline \multicolumn{3}{|l|}{ Oklahoma } \\
\hline $\begin{array}{l}\text { Advocate } \\
\text { Allen }\end{array}$ & $\begin{array}{l}\text { Logan County News } \\
\text { Crescent }\end{array}$ & $\begin{array}{l}\text { Grand Lakes } \\
\text { Shoppers Guide } \\
\text { Grove }\end{array}$ \\
\hline $\begin{array}{l}\text { Lake Keystone News } \\
\text { Mannford }\end{array}$ & & \\
\hline \multicolumn{3}{|l|}{ Pennsylvania } \\
\hline $\begin{array}{l}\text { Advertiser } \\
\text { McMurray }\end{array}$ & $\begin{array}{l}\text { Shopping News of Lan } \\
\text { Ephrata }\end{array}$ & rcaster County \\
\hline $\begin{array}{l}\text { Bucks-Mont Courier } \\
\text { Harleysville }\end{array}$ & $\begin{array}{l}\text { News } \\
\text { Lancaster }\end{array}$ & $\begin{array}{l}\text { Lancaster Farming } \\
\text { Lititz }\end{array}$ \\
\hline$\frac{\text { Rhode Island }}{\begin{array}{l}\text { Narragansett } \\
\text { Wakefield }\end{array}}$ & & \\
\hline
\end{tabular}


South Carolina

Sentinel

News

Southeastern

Pickens

Westminster

Farm Press

Williston Bay

Columbia

Barnwell

South Dakota

Courier

Bison

Record

Reminder

Arion

Mobridge

Trader

Tribune Register

Leader

Pierre

Tyndall

White

Tennessee

Jackson County Sentinel Cannon Courier

Gainsboro

Woodbury

Southeastern

Farm Weekly

Knoxville

Texas

News

Tribune

Calvert

Hopodar

Bogata

Weekly Livestock

Reporter

Southw
Dallas

Fort Worth

West

Texas Ranch

News

San Antonio

Virginia

Courier-Record

Blackstone

Farm \& Livestock Boyce

The Chronicles of the Horse Middleberg

West Virginia

Calhoun Chronicle

Grantsville

The Valley Digest Lewisberg

Advocate

Parsons

Wisconsin

Wild River Advertiser

Frederic

Enterprise-Herald

Times

Luck

Peshtigo

Wisconsin State Farmer

Badger Farm Bureau

Home News

Waupaca

News, Madison

Spring Green

Manitoba

Free Press Report on Farming

Ontario

Western Ontario Farmer

Saskatchewan

Western Producer

New Brunswick

Gleaner 
Rocky Mountain Time Zone

\begin{tabular}{|c|c|c|}
\hline $\begin{array}{l}\text { Apache Sentinel } \\
\text { Apache Junction }\end{array}$ & $\begin{array}{l}\text { Buckeye Valley } \\
\text { News, Buckeye }\end{array}$ & $\begin{array}{l}\text { Eastern Arizona } \\
\text { Courier, Safford }\end{array}$ \\
\hline $\begin{array}{l}\text { Tombstone Epitaph } \\
\text { Tombstone }\end{array}$ & $\begin{array}{l}\text { News-Enterprise } \\
\text { Yuma }\end{array}$ & \\
\hline Colorado & & \\
\hline $\begin{array}{l}\text { Adams County standard } \\
\text { Brighton }\end{array}$ & $\begin{array}{l}\text { Record Stockman } \\
\text { Denver }\end{array}$ & $\begin{array}{l}\text { Enterprise } \\
\text { Holoyoke }\end{array}$ \\
\hline $\begin{array}{l}\text { Arkansas Valley Journal } \\
\text { La Junta }\end{array}$ & $\begin{array}{l}\text { Pioneer } \\
\text { Yuma }\end{array}$ & \\
\hline $\begin{array}{l}\frac{\text { Idaho }}{\text { Eastern Idaho Farmer }} \\
\text { Idaho Falls }\end{array}$ & $\begin{array}{l}\text { The Owhee Nugget } \\
\text { Marsing }\end{array}$ & $\begin{array}{l}\text { Citizen } \\
\text { Preston }\end{array}$ \\
\hline $\begin{array}{l}\frac{\text { Montana }}{\text { Montevyo News }} \\
\text { Billings }\end{array}$ & $\begin{array}{l}\text { Pioneer } \\
\text { Ronan }\end{array}$ & $\begin{array}{l}\text { Herald } \\
\text { Sidney }\end{array}$ \\
\hline $\begin{array}{l}\text { Madisonian } \\
\text { Virginia City }\end{array}$ & & \\
\hline $\begin{array}{l}\frac{\text { New Mexico }}{\text { Sandoval County Progress }} \\
\text { Bernalillo }\end{array}$ & $\begin{array}{l}\text { Mid Valley abserve } \\
\text { Corrales }\end{array}$ & $\begin{array}{l}\text { Round-up } \\
\text { University } \\
\text { Park }\end{array}$ \\
\hline $\begin{array}{l}\frac{\text { Utah }}{\text { Millard Coúnty Progress }} \\
\text { Fillmore }\end{array}$ & $\begin{array}{l}\text { Clearfield Courier } \\
\text { Roy }\end{array}$ & $\begin{array}{l}\text { Express } \\
\text { Vernal }\end{array}$ \\
\hline $\begin{array}{l}\frac{\text { Wyoming }}{\text { Palatte County Record }} \\
\text { Times, wheatland }\end{array}$ & $\begin{array}{l}\text { Post } \\
\text { Pine Bluffs }\end{array}$ & $\begin{array}{l}\text { Guide Review } \\
\text { Lingle }\end{array}$ \\
\hline
\end{tabular}


. 


\section{APPENDIX B}

\section{SAMPLE QUESTIONNAIRE AND RESPONSES}

The following pages present a sample of the questionnaire that was sent to respondees of the newspaper ads. Responses to the questions are tabulated by both number and as a percentage of the total responses.

Discrepancies in the totals of the responses per question can be found. For example, it would appear that the total number of responses in question 10 should equal the total number of responses in portion (a) of question 9, but they do not. There are a few other discrepancies of this type. It was found by reviewing the original questionnaires that some had more than one answer checked off for certain questions, while others were not answered at all. Tabulation was made by considering number of responses to a specific question. No attempt was made to adjust responses to make totals agree. 
AMERICAN WIND ENERGY ASSOCIATION SITING STUDY QUESTIONNAIRE

1. Person completing this questionnaire:

Name:

Address :

City, state, zip Códe:

Telephone:

2. Location of windmill (if different from above):

Address :

City, state:

3. What did you use your windmill for?

RESPONSES $\&$ OF RESPONSES

a. water pumping

43

248

b. radio

29

$16 \%$

c. home appliances

66

$37 \%$

d. farm equipment (electrical) 21

$12 \%$

e. farm equipment (mechanical)

2

18

f. other (please specify)

18

$10 \%$

4. Who was the manufacturer?
a. Aeromotor
164
$57 \%$
b. Dempster
8
c. Heller-Aller
2
18
d. Halladay
0
$0 \%$
e. Bucknell
0
08
f. Jacobs
49
$17 \%$
g. Wincharger
17
$6 \%$
h. Allied
0
08 
RESPONSES $\because$ OF RESPONSES

i. Dyna Technology

5

28

j. Winco

0

$0 \%$

k. Aerodyne

$0 \%$

1. Ruralite

0

$0 \%$

m. Nelson

0

$0 \%$

n. Delco

0

0 단

o. Air Electric

1

$0 \%$

p. Paris-Dunn

0

$0 \%$

q. Perkins

1

$0 \%$

r. Hebco

0

$0 \%$

s. Wind King

0

$0 \%$

t. Dunlite

25

$9 \%$

u. Elektro

4

$1 \%$

v. other (specify)

10

$3 \%$

w. don't remember

3

18

5. When was your windmill installed? month year

6. Who installed it?
a. yourself
71
$52 \frac{0}{3}$
b. previous owner
17
$12 \%$
c. salesman or distributor
31
$23 \%$
d. manufacturer
4
$3 \%$
e. contractor
9
$7 \%$
f. other (please specify)
4
$3 \%$ 


\section{RESPONSES $\&$ OF RESPONSES}

7. How high was the tower?
a. $30 \mathrm{ft}$. or less
b. 30 to $50 \mathrm{ft}$.
c. over $50 \mathrm{ft}$.
32
278
d. exactly ft.
$0 \%$

8. How was the tower height selected?
a. $\cos t$
b. that's all that was available
c. to clear obstructions
66
$44 \%$
d. installers recommendation
e. manufacturers recommendation
21
f. other (please specify)
17
118

9. Did (do) you know the average wind speed in your area?
a. yes
79
$59 \%$
b. no
54
$41 \%$

10. If the answer is yes, how did you learn what the wind speed was?

a. from wind measurements

b. local wind data (for example, an airport)

c. from a neighbor

d. from the windmill installer or salesman

e. other (please specify)

11. What type of land was (is) the windmill located on? a. hilly 
b. flat

c. trees over $50 \mathrm{ft}$.

d. trees under $50 \mathrm{ft}$.

e. other (please specify)
53

$36 \%$

18

$12 \%$

18

$12 \%$

7

12. Did this influence where you put the windmill, and if so, how?

13. Did the use of the energy produced influence windmill location, and if so, how?
a. location of well
b. where the power was to be used
69
528
c. location of buildings
30
228
d. other
6
$4 \%$

14. What other factors affected the location of the windmill?
a. family wishes
19
$20 \%$
b. tower height
43
44 웅
c. cost
12
$12 \%$
d. legal considerations
5
58
e. other
18
$19 \%$

15. How long was your windmill in operation? months years

16. How often did it require maintenance?
a. more than once a year
33
$34 \%$
b. once a year or less
50
$52 \%$
c. never
13
14 
17. What kind of maintenance did it require?
a. lubrication
69
598
b. replacement of parts
38
328
c. other
10
98

18. Were you satisfied with its operation?
a. produced as much power as expected
85
738
b. did not produce enough power
13
118
c. broke down often
16
$14 \%$
d. other
2
28

19. Why did you stop using the windmill?

a. broke down in high winds (how strong do you think the winds were?) 3

$2 \%$

b. broke in normal operation

c. was vandalized

0

$0 \%$

d. no longer needed the power

31

268

e. still using it

67

568

f. other

108

This space is provided for any additional comments you might have, or if there was not enough space to answer the question.

In answering questions 20-26, assume that you are considering purchasing a windmill at the present time.

20. What would you be willing to spend to determine the wind power available at your farm?

a. less than $\$ 10$ 


\section{RESPONSES 8 OF RESPONSES}
b. $\$ 11$ to $\$ 50$
27
228
c. $\$ 51$ to $\$ 100$
13
$10 \%$
d. $\$ 101$ to $\$ 250$
4
38
e. $\$ 251$ to $\$ 500$
38
318
f. more than $\$ 500$
8
68

21. Where would you go first for information on windmills?
a. agricultural extension agent
14
108
b. farmers organization such as the Grange or Farm Bureau
c. farm machinery dealer
0
08
d. windmill dealer
77
588
e. other (please specify)
16
128
f. don't know
20
158

22. Where would you go first for information on the wind in your area?
a. closest airport
27
198
b. National weather Service
50
348
c. windmill dealer
27
198
d. I have my own wind instruments
17
$12 \%$
e. other (please specify)
10
$7 \%$
f. don't know
13
98

23. Where would you go first for information on selection of a specific location for the windmill to gain the most wind power?
a. agricultural extension agent
9
$7 \frac{7}{2}$
b. farm organization
0
$0 \%$
c. farm machinery or windmill dealer 

d. National Weather Service
15
118
e. meteorologist
f. other (please specify)
11
98
g. don't know
h. would not select location on the basis of wind power

24. How much would you be willing to spend to identify the location which would provide the most wind power?
a. less than $\$ 10$
38
438
b. $\$ 11$ to $\$ 50$
33
378
c. $\$ 51$ to $\$ 100$
8
98
d. $\$ 101$ to $\$ 250$
e. $\$ 251$ to $\$ 500$
2
$2 \%$
f. more than $\$ 500$
1
18

25. What size windmill would you want?
a. less than $5 \mathrm{kw}$
27
$20 \%$
b. 6 to $25 \mathrm{kw}$
66
498
c. 26 to $50 \mathrm{~kW}$
4
$3 \%$
d. 51 to $100 \mathrm{~kW}$
8
68
e. more than $100 \mathrm{kw}$
6
48
f. don't know
24
$18 \%$

26. What would you use a windmill for?
a. pump water
b. Produce electricity for
c. produce electricity for home use

27

$18 \%$ 

d. other (please specify)
12
$8 \%$
e. don't know
2
$1 \%$

27. Do you know of a dealer who sells windmills for pumping water?
a. yes
61
458
b. no
73
$55 \%$

28. Do you know of a dealer who sells windmills for generating electrical power?
a. yes
80
$61 \%$
b. no
51
$39 \%$

29. Are you aware of any governmental programs supporting wind energy research and development?
a. yes
80
638
b. no
47
378

30. Would you be willing to participate in future studies regarding the use of wind energy?
a. yes
101
$81 z$
b. no
23
198

This space is provided for any additional comments you might have, or if there was not enough space to answer questions $20-30$. 


\section{APPENDIX C}

\section{PAST AND PRESENT WECS DISTRIBUTORS}

Siting information was sought from past and present WECS distributors. The following presents a list of distributors contacted. 



\section{PAST AND PRESENT WECS DISTRIBUTORS}

Enertech

P. O. Box 420

Norwich, VT 05055

American Wind Turbine

1016 E. Airport Rd.

Stillwater, OK 74074

WinPower

$1207 \mathrm{E}$. Avenue

Newton, IA 50208

Windlite Alaska

Box 43

Anchorage, AK 99510

Real Gas \& Electric

P. O. Box A

Guerneville, CA 94306

Sencenbaugh Wind Electric

P. O. Box 11174

Palo Alto, CA 94306

Environmental Energies

Front Street

Copemish, MI 49625

Bristol Aerospace LTD.

P. O. Box 874

Winnipeg, Manitoba

Canada R3C 2B 4

ARCRAD Itd.

150 Consumers Rd.

Willowdale, Ontario

Canada M2J $1 T 9$

H. J. Godwin Ltd. Quenington Glous. England GL7 5BX

J. Taylor

88 Hull Rd.

Wcodmansey, East Yorkshire England HUl7 $0 \mathrm{TH}$
Walter Schoenball

45 Geneve 1211

Switzerland

Energy Alternatives

P. O. Box 233

Leverett, MA 01054

Independent Energy Systems 6043 Sterrettania Rd. Fairview, PA 16415

North Wind Power

Box 315

Warren, VT

Bob Dodge Automatic Power

Pennwalt Corp.

213 Hutcheson Street

Houston, TX 77023

Grumman Aerospace Corp.

4175 Veterans Memorial Hwy.

Ronkon Koma, NY 11779

Dominion Aluminum Fabrication 3570 Hawkestone Road

Mississauga, Ontario L5C 2V8

Quirk's Victory Light Co.

33 Fairweather st.

Bellevue Hill, N.S.W.

Australia

Enag S.A. Rue de Pont-I'Abbe Quimper (Finistere)

France

Aerowatt S.A.

37 Rue Chanzy

75 - Paris l1e France

Dunlite Electrical

Div. of Pye Industries

21 Fromme street

Adelaide 5000, Australia 
Elektro G.m.b.H.

winterthur

St. Gallerstrasse 27, Schweiz

Dyna Technology

Ecological Science corp.

Sioux City, IA 51102

Repair Works

Taiwan Power Company

61-Yuh Cheng st.

Na n-Kong, Taipei

Taiwan

Cytra, Inc.

Abrosio Bldg.

Buendia, Cor Bantista Makati Phillipines

Westwind Development

108 Wedgewood Drive

Calgary, Alberta T3C $3 \mathrm{G} 6$

Par Industrial Contractors

P. O. Box 2328

Prince George, B.C.

Bugden \& Associates

72 Broadview Avenue Pointe Claire, P.Q.

Canada H9R $3 \mathrm{Z} 4$
Dempster Industries

711 S. 6

Beatrice, NB

Aermotor Div. of Braden Ind. 800 F. Dallas St.

Broken Arrow, OK 74012

Maschinenfabrik

Ludwig Bening

2847 Barnstorf

P. O. Box 171

Germany

Aetna Steel Industries

613 Roman Santos B1dg.

Plaza Coiti, Manila

Phillipines

The Wind Turbine Co. of Canada

George Fletcher Sales

Elmira, Ontario

International Aeradio

70 Don Park Rd., Unit 15

Markham, Ontario L3R IG4

HPL Engineering

4 Cessar Avenue

Kemptuille, Ontario

Canada KOG IJO 
APPENDIX D

\section{SITING GUIDELINES}

A review was made of siting guidelines offered by WECS

distributors. Pertinent excerpts taken from owners' manuals of several distributors follow. 



\section{SITING GUIDELINES}

\section{Jacobs Wind Electric}

Jacobs wind Electric systems were manufactured in Minnesota from 1931-1956. This company was the largest (dollar volume) manufacturer of wind machines of that period. of the electrical generating machines surveyed, 468 were Jacobs. The diameter of these generators was a nominal 14 feet, and the electrical capacities ranged from 1,800 watts to 3,000 watts. It is thought that the success of the Jacobs marketing effort was due largely to his efforts to sell all the subsystems: storage, towers, appliances, etc., with his units.

The recommendations extracted from the owner's manual:

"The tower should be on the highest ground near the batteries. The tower should be of sufficient height to place the plant well above all surrounding trees and buildings by not less than 20 feet. Don't sacrifice a higher and better location just to save a few feet of wire. Remember, the plant must be installed where it will be above surrounding trees and buildings, because installing it 100 or 200 feet away will not eliminate the effect of obstructions on the wind currents."

\section{Wind Power Manufacturing Company}

Wind Power sold WinPower wind generators from 1932-1956. This company bought out Paris-Dunn and Ruralite (smaller wind electric manufacturers) in the 1930's and at its peak had 140 distributors. Twenty to twenty-five percent of their business was export, with Argentina being the largest importer. They 
had special installation crews and their own finance company. They refused to finance customers who would not follow their recommendation and found that the greatest problem was convincing farmers to purchase a tower of sufficient height. The WinPower was 12 feet in diameter and had either 1250 watt or 1800 watt generators.

The recommendation on siting in the owner's manual was: "The illustration (Figure D-I) shows why the tower must be fully 20 feet higher than all trees or obstructions within .500 feet. If not, the amount of power produced will be drastically reduced and little benefit will be secured in the lighter winds. The tower should be located on the highest ground available, preferably not over 200 feet from the batteries."

\section{Allied Wind Electric}

The exact dates of manufacture of the Allied Wind Electric Plants based in Spencer, Iowa, are not clear. They began in the early 1930's and operated until the late 1940's when they were purchased by Jacobs Wind Electric. Many of the design features of the Allied machines were later incorporated in Jacobs wind plants. These machines were a nominal 12 feet in diameter and were supplied with 1200 watt or 1600 watt generators.

Siting recommendations from the owner's manual read:

"Before starting to install your Allied wind Electric Plant, recheck the location and height of your tower to be sure that when the tower is erected and the plant installed, it will not be less than 25 feet above all obstructions within a 500-1000 foot radius. This is important as the monthly output of your plant can be reduced $1 / 4$ to as much as $1 / 2$ its regular output 

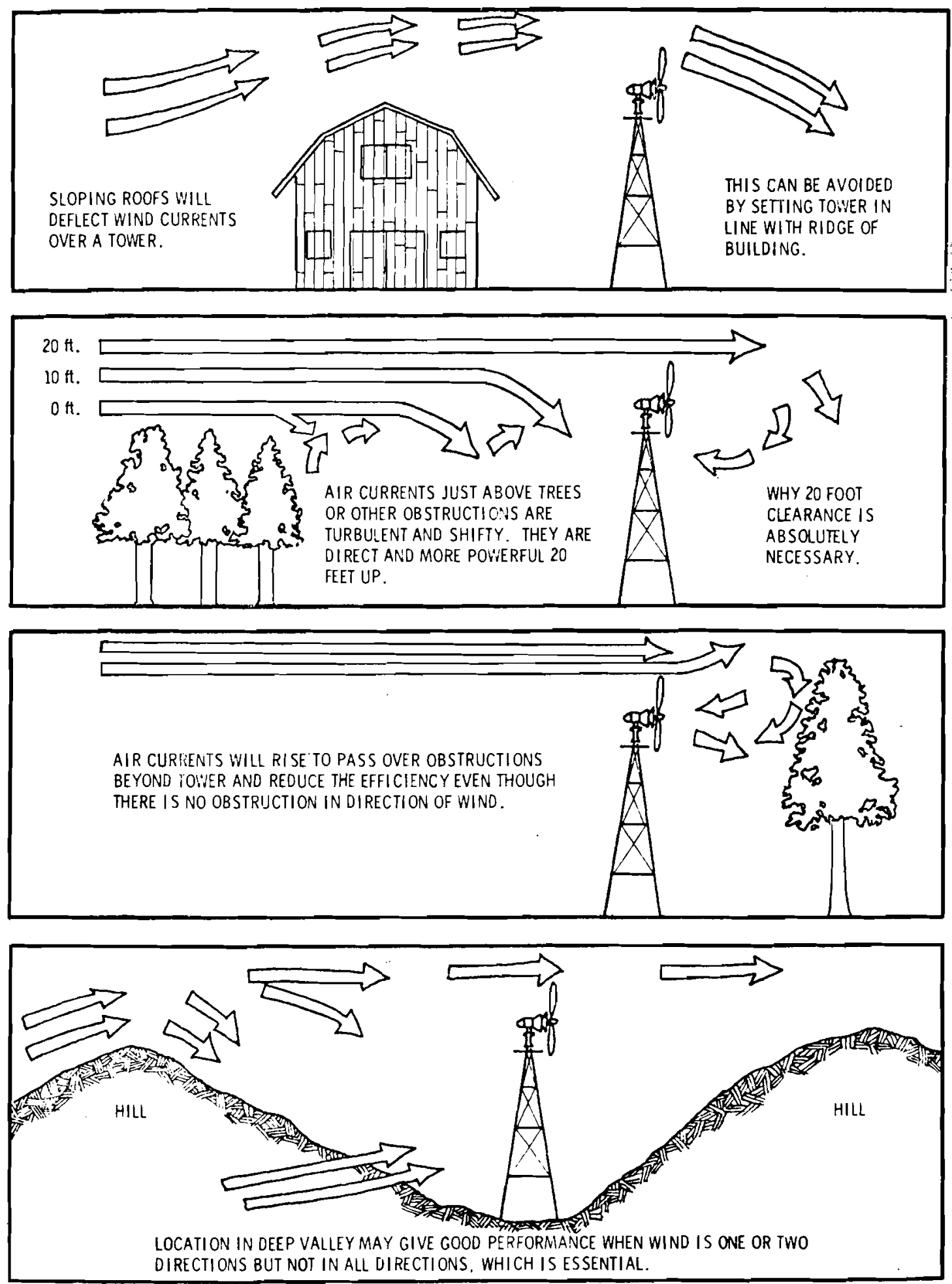

FIGURE D-I. Suggestions for the Proper Location of Your Tower (based on Winpower drawing) 
if a row of trees or a big barn can deflect the wind currents before they reach your plant. The added cost of a higher tower will be many times repaid in the greater monthly output of your plant year after year. Remember, a wind electric plant depends on the wind for its power. Don't reduce its output and handicap its performance by failing to place it in a favorable location.

The standard distance for the tower location is 90 to 100 feet from the basement or batteries, but if higher ground and better wind currents can be secured at 150 to 200 feet, additional hook-up wire should be secured and the tower set at the better wind location."

Aerowatt, S.A.

Aerowatt machines are manufactured in France, primarily for remote power applications. The capacity of these units ranges from 24 watts to 4,100 watts. The emphasis in the design is on extreme durability in hostile environments. A primary application is navigational aids, where the traditional power supply is primary batteries that produce power at a cost of roughly $\$ 20 / \mathrm{kWh}$. Aerowatt has approximately 100 machines in service around the world and 20 in this country, primarily in the Gulf of Mexico. System size is based on annual energy production, with a 2 to 2.5 safety factor in terms of energy production capacity. In the Gulf of Mexico applications, annual average wind speeds are well known. Tower height is not an issue in that the machines are mounted on platforms well above the surface of the water, often 100 feet or more. Site analysis is not performed in these applications except for a prediction of annual energy production. 
The siting guidelines that are given in the company manual:

"The operation of a wind generator is a function of the quality of the installation. Wind generators must be installed on supporting structures which insure clearance of neighboring obstacles and so place them in a purely laminar wind stream.

"For example, a cylindrical obstacle will create whirlwinds with a rotation axis parallel to the cylinder, and which will exist up to a distance equal to ten times the obstacle diameter.

"Another example is found on the top of cliffs, or the summit of slopes where rising air currents produce whirlwinds with a horizontal axis and which can reach high altitudes.

"When testing a site, a qualitative method consists in bringing in one way or another, ribbons 1 or 2 meters long, at the height at which the wind generator will be installed. The way the ribbons react will rapidly show whether the airflow is laminar or boisterous.

"Aerowatt can only guarantee its equipment if they have been correctly installed. For this purpose, send Aerowatt a survey of the ground area chosen for the wind generator site over a radius of 100 to 200 meters. Aerowatt will then let the user know if it agrees with the location."

Dunlite

The Dunlite, manufactured in Australia, has been the largest selling wind machine in recent years. Approximately $23 \%$ of the installations surveyed were Dunlites. The reason for this lies primarily in the comparatively low cost. These machines are a nominal 12 feet in diameter and have a 2,000 watt $\in$ lectrical capacity.

The siting recommendations given in the owner's manual:

"Examine the proposed site to make sure that the plant will receive the maximum force of the prevailing wind for the particular area. 


\begin{abstract}
"Most of the criticism of unsatisfactory operation of a wind driven plant is due to their installation in an unsuitable position or low towers.

"Maximum efficiency is only possible where the plant operates in a clear and steady airstream.

It is essential that the plant is at least 15-20 feet clear of all obstacles (buildings, trees, etc.) and the tower is sufficient height to reduce ground disturbance - a minimum of 40 feet is recommended.

"Make sure that the plant is at least placed between the direction of prevailing winds and any buildings, etc. Any object higher than the plant will cause a disturbance in air flow for approximately 300 yards in front of the plant and 50-100 yeards behind the plant.

"In hilly areas it is better to place the plant 200-300 yards away from the building housing the batteries and control equipment if a better wind location is thus obtained.

"The steadier the air flow in which the plant is operating, the higher the average output, and the less strain is placed on the plant due to the frequent changes in wind direction."
\end{abstract}

Winco

Winco, a division of Dyna Technology in Sioux City, Iowa, manufactures a small wind system used for battery charging applications. This machine is 6 feet in diameter and produces 200 watts. Winco is the only manufacturer in operation today from the pre-REA period.

Their siting recommendations, taken from the owner's manual:

"For good performance, it is necessary that the wind driven generator be mounted where the wind from all directions has an uninterrupted flow to the propeller. Any obstruction such as trees, hills, or buildings, even though they are somewhat lower than the charger, will set up rough air currents that seriously decrease the generator output. These 'rough' air currents have lost a large part of their power and are continually shifting from one direction to another and also shift upward or downward. They also tend to increase 
vibration. All these factors should be considered in selecting a satisfactory location for the charger. The higher the charger the better, for the air currents are smoother and steadier further from the ground. For good operation, the charger should be mounted at least 15 feet above any obstructions within 400 feet.

"If the charger cannot be mounted any higher than surrounding obstructions, it should be more than 400 feet from these obstructions. If the charger cannot be mounted as high as the surrounding obstructions, it should be placed at least 800 feet from these obstructions. Neither of these installations are recommended in preference to an installation in which the charger is mounted considerably above the obstruction. They are merely substitutes for the better type installation.

"Another important fact to remember is that the charger should be mounted as close to the battery as possible. The further the charger is mounted from the battery, the greater the loss of energy in the wires. Since 100 feet is the maximum recommended distance between the charger and the battery and since the battery will ordinarily be kept in the house, one of the methods suggested in this book should be followed to mount the charger close to the house and up high enough to receive an unobstructed sweep of the wind. Remember that if the charger is placed further from the battery, the wiring cost will be greater for two reasons: 1) the wire must be longer, and 2) the wire must be of larger diameter.

"In case there is no way of installing the charger near the house and above surrounding obstructions, it is possible to install the charger at a distance from the house in some unobstructed spot. For greater convenience it may be mounted on a two or four wheeled cart and moved from one location to another depending on the direction of the wind. Unless a very heavy cart is used, the tower should always be guyed to prevent it from blowing over in strong winds. The battery in this case will have to be taken to the wind generating plant for charging.

"The service and satisfaction of a wind driven generator depends so much on the proper location that it cannot be emphasized too strongly that to make a good installation, it is absolutely necessary that the charger not be shielded from the wind in any direction. 
"The top illustration (Figure D-II) shows a type of installation superior to either of the other two for two reasons: First, the charger is mounted at least 15 feet higher than any obstructions within 400 feet as recommended and second, the charger is mounted close to the house on a pole so that no vibration and rumble is heard in the house. The first illustration is the ideal type, and although a little more difficult, the extra time and money spent on this type of installation will more than pay for itself in the quiet and efficient service it renders.

"In the second illustration, the installation is better than the one shown at the bottom of the page because the trees are not as high and the 10 foot tower has been used instead of the 5 foot tower. This type of installation will give better performance at all times than the one illustrated below because the air currents will be smoother and steadier.

"Note in the bottom diagram the surrounding trees are higher than the propeller. With high winds this type of installation will produce some current, but do not expect good results with this type of installation. The air currents will be rough and very unsteady, and the generator output will be low."

Northwind Power Company

Northwind Power Company is one of the major wind machine distributors currently in operation in this country. They sell reconditioned Jacobs machines and a more recent, small ( $1 \mathrm{~kW}$ ) machine manufactured by Aero Power. They also offer site surveys which consist of recording the wind velocity distribution and attempting to develop a correlation with existing weather Bureau data. They sell a variety of anemometry hardware including a pilot tube-type sensor, wind-run recorders, a wind velocity distribution recorder 110 registers, 1 minute average), and strip chart recording anemometers. 


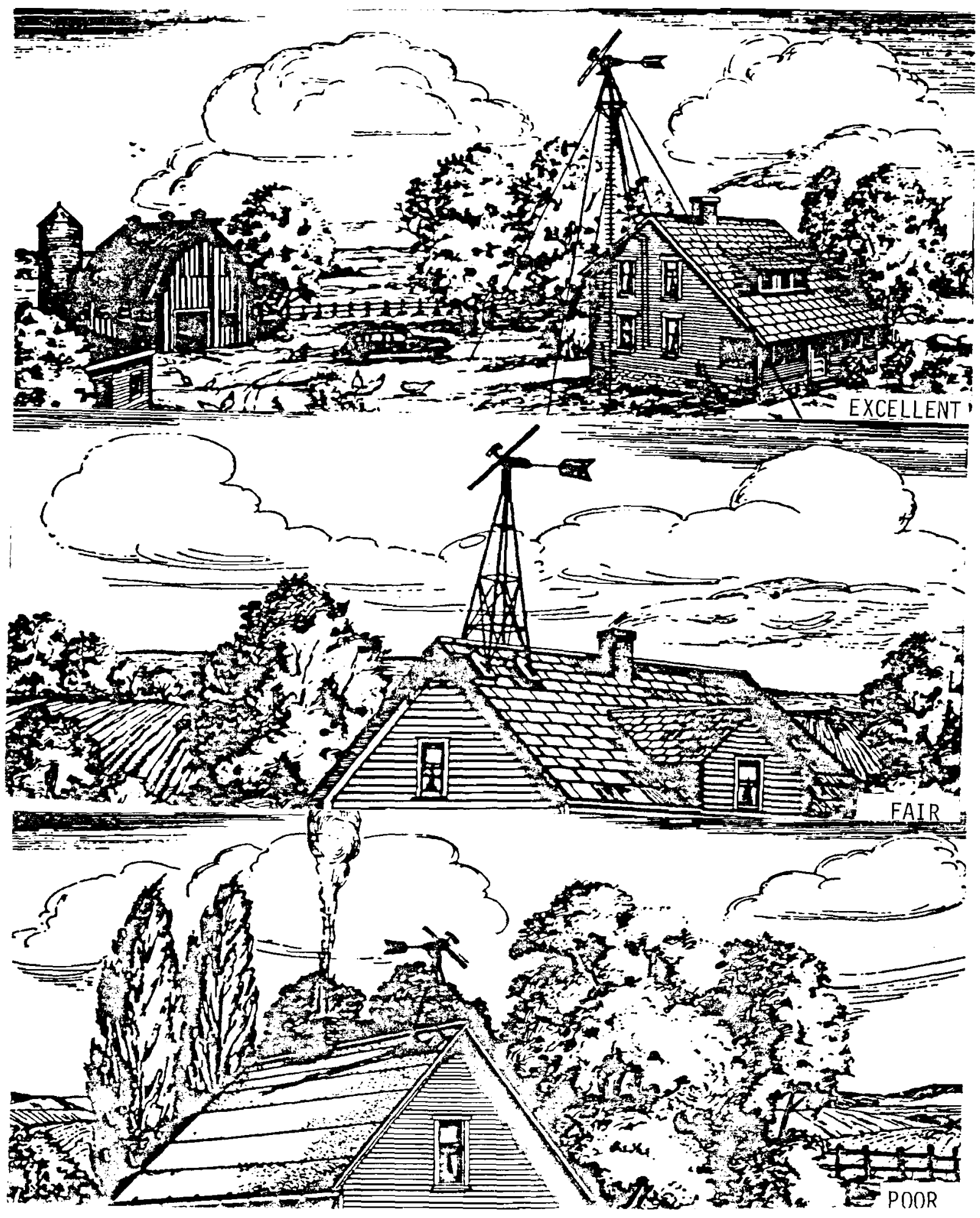

FIGURE D-II. Types of Charger Locations (from WINCO) 
In their catalogue, they offer the following comments on siting:

"The selection of the correct tower height for the wind system is a very important consideration. Improper tower height or location can significantly limit the wind generator output. The rule of thumb to determine correct tower height is that the tower should be 20 feet above any obstructions within 500 feet. Wind speeds at 40 feet above the ground can be as much as 50\% stronger than ground winds. Since the power from the wind is proportional to the cube of the velocity, correct tower height can significantly affect the number of kilowatt hours a given system will produce."

(They also published a drawing similar to WinPower: Figure D-III.)

Enertech, Inc.

Another major distributor of wind driven generators in this country is Enertech. They distribute the Swiss made Elektro (the largest Elektro is 20 feet in diameter with a $10 \mathrm{~kW}$ electrical capacity) and the Dunlite, previously mentioned. In response to requests for information on the use of wind energy, they have prepared a paper entitled:

"Planning a Wind Energy Conversion System: Basic Principles, Components of a System, Estimating Wind Availability, Estimating Power Requirements."

The section from that publication reads:

"Regardless of what winds are dominant, care must be taken to select a site where there will be the least obstruction to free wind flow, and particularly the free wind flow of the 10 to $25 \mathrm{mph}$ winds. Large obstructions such as high hills are likely to cause 'wind shadow' reducing the total wind availability. Smaller obstructions such as houses, trees, and small hills or sharply rising hills behind the site are likely to cause either interference or turbulence, impeding the usable wind flow. 

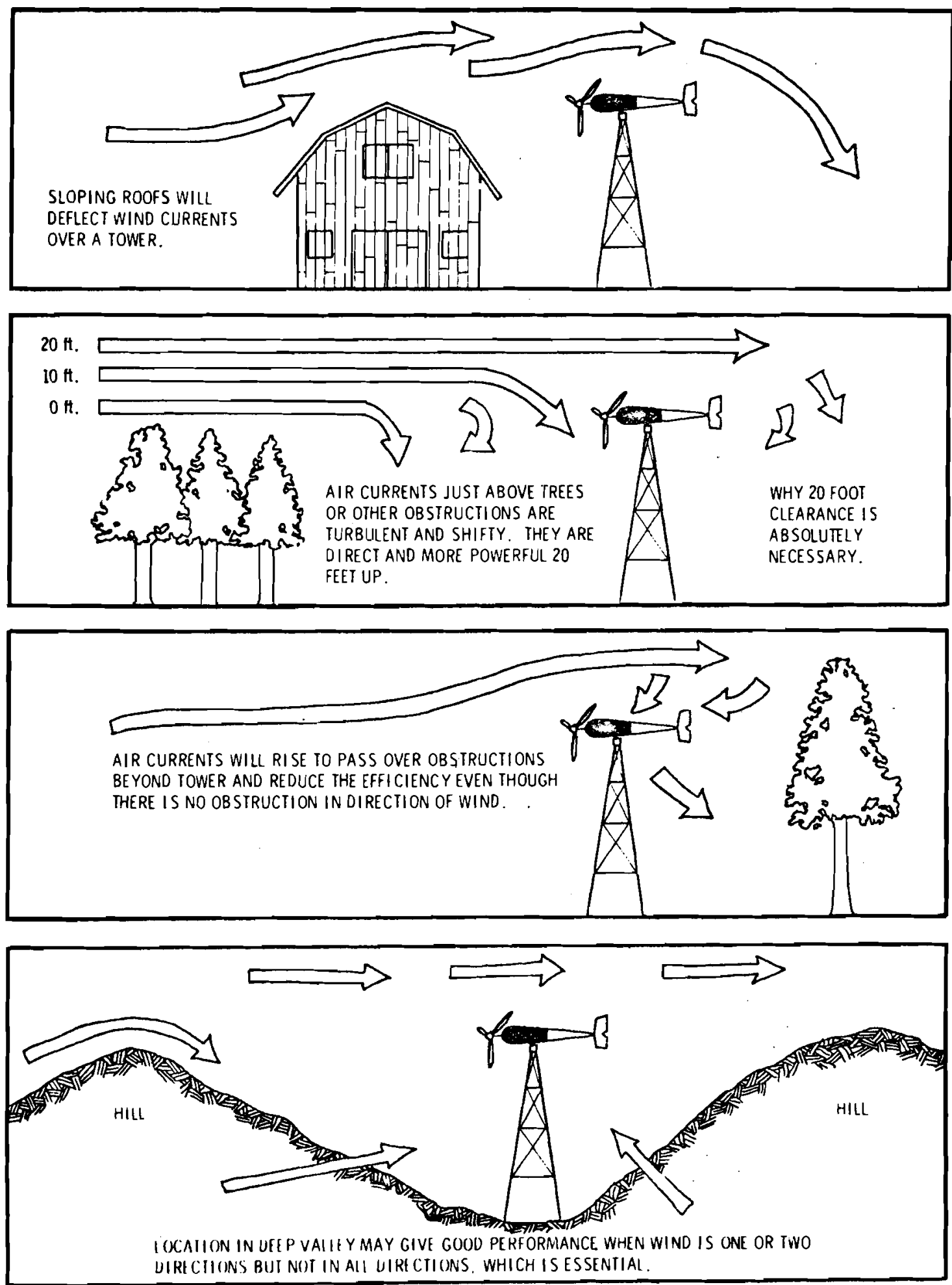

FIGURE D-III. Selection of Tower Heights (based on Northwind drawing) 
"The ideal tower site is also close to the point where the power will be stored and consumed, minimizing the investment in heavy gauge, low resistance wire running from the tower to the control panel and batteries. Next to your house or shop is ideal (if the tower is high enough); within 50 to 200 feet is fine; beyond 250 feet you will increase your cost substantially.

"After locating your tower the next step is to establish the minimum tower height for the particular site. Ground friction can reduce the wind speed by 50\%, so the generator should always be mounted at least 30 feet and preferably 40 feet above the ground. It should also be mounted at least 20 feet and preferably 30 feet above any trees or buildings within 400 feet that might either block the winds or cause turbulence. Turbulence not only reduces wind availability but may prove hazardous to the generator assembly by exerting unequal wind pressure on the individual blades. Remember that the obstacles behind the tower can create the same problems of turbulence as obstacles in the front. Remember too, that the cost of an additional 10 feet or even 30 feet of tower height is minor compared to the increased power you will obtain from the additional wind.

"One simple method for detecting turbulence at your tower site is to put up a pole with one or two ribbon streamers. In a good breeze if the ribbons fly out straight and steady, the wind flow is smooth. If you see a lot of flapping, there is turbulence at that level, and you should either locate your wind generator higher or look for a better site." 


\title{
APPENDIX E
}

\section{WIND ENERGY BIBLIOGRAPHY}

\begin{abstract}
A Iisting of the literature related to wind energy, wind energy conversion, and wind energy conversion systems which was reviewed is presented in the following pages. The listings of significant papers and reports have been annotated.
\end{abstract}




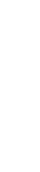


1. Academy of Sciences (USSR), "METHODS OF ANALYSIS OF WIND POWER POTENTIAL TO FIVE REGIONAL CHARACTERISTICS", 1963, $190 \mathrm{p}$.

2. Ailleret, P., "WIND ENERGY: ITS VALUE AND CHOICE OF SITE FOR EXPLOITATION", Review Gen. Elec., Paris, Vol. 55, pp. 103-108, March 1946 .

The problem of wind power utilization is discussed, including determination of wind power per square meter obtained yearly from surfaces subjected to wind action, and systematic prospecting for favorable sites using a simple anemometric device which calculates wind speed with the aid of a special electric meter. A description is given of a program for site selection which will make it possible to determine the energy which can be produced by the wind engine used. (Technology Application Center, TAC, review)

3. Ailleret, P., "LA RECHERCHE DES SITES QUI POURRAIENT CONVENIR A UNE UTILISATION DE L'ENERGIE DU VENT", La Meteorologie, pp. 145-152, April-June, 1948.

To assess wind power possibilities, a wind energy survey is necessary. A wind energy meter developed for this purpose, the choice of site areas, and the first results of the survey are described. (TAC review)

4. Alaka, M.A., editor, "THE AIRFLOW OVER MOUNTAINS", Tech. Note N. 34, WMO-No. 98 TP.43, Secretariate of the World Meteorological Organization, Geneva, Switzerland, 1961.

5. Anderson, S.R., "A COMPARISON OF MONTHLY WIND MILEAGE FROM TYPE 45B AND U2A ANEMOMETERS", Department of Transport, Meteorological Office, Ottawa, Canada, 1956.

6. Andreyev, I.D., "WIND GUSTINESS WITHIN AN HOURLY INTERVAL", Voprosy Vetroenergetiki (questions of wind energy production), Moscow, an SSSR publication, 1959.

7. Anufriev, A.F., Supriaga, IA.A., "WIND ENERGY - ENERGETIC RESOURCES OF THE REPUBLIC KOMI, ASSR", Acad. of Sciences of the U.S.S.R., Filiale, Komi. Pp. 28-31, Moscow, 1963. 
8. Argand, "MEASUREMENT OF THE CHARACTERISTIC PARAMETERS OF WIND POWER FOR THE SELECTION OF FAVOURABLE SITES FOR WINDDRIVEN GENERATORS", Proceedings of the U.N. Conference on New Sources of Energy, W/35, Rome, August 1961, Vol. $\underline{7}$, $\overline{U . N} .$, New York, 1964 .

Time constants of Robinson, Papillon, and Ailleret anemometers considered as well as the Best-Romani type. Variation among these suggest that standards be established for presenting wind power data. World-wide wind power potential is discussed, a standard anemometer height above 20 meters is suggested, and projections with respect to the direction of wind power development in Europe and in developing countries are offered. (SB)

9. Aujesky, L., "COMPUTATION OF QUADRADIC AND CUBIC MEAN VALUES OF WIND VELOCITY FOR THE ESTIMATION OF AVAILABLE WIND POWER", Idojaras 55 (3/4): 79-81, March/April 1951.

Representations of wind conditions by average values of wind velocity are not sufficient to determine wind power at a given location. Theoretically wind power is proportional to the third power of wind and velocity. The usable power from sychonous generators is proportional to the square of the wind speed. Therefore it is necessary to compute quadratic and cubic means of wind velocity.

10. Ballester, Miguel, "SPECULATIVE METHODS IN WIND SURVEYING", Proceedings of the U.N. Conference on New Sources of Energy,

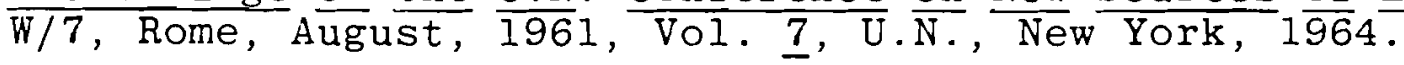

Assumes the site can be selected and is not predetermined by the load center. Discusses field procedures and statistical procedure for comparing sites. Three sites in Spain were instrumented and statistically compared. The author suggests that site analysis is in its exploratory stage and that a mixture of subjective evaluation and rigorous scientific method must by necessity be used in site selection. (SB)

11. Barasoain, J.A. and Fontan, L., "PROSPECTING FOR WIND POWER WITH A VIEW TO ITS UTILIZATION", Proceedings of the U.N. Conference on New Sources of Energy, W/16, Rome, August, 1961 , Vol. I, United Nations, New York, 1964.

This paper analyzes methods used in compiling, from the data furnished by meteorological services and the results obtained from specific wind prospecting networks, statistics for use in studies of wind power utilization. 
1. Academy of Sciences (USSR), "METHODS OF ANALYSIS OF WIND POWER POTENTIAL TO FIVE REGIONAL CHARACTERISTICS", 1963, $190 \mathrm{p}$.

2. Ailleret, P., "WIND ENERGY: ITS VALUE AND CHOICE OF SITE FOR EXPLOITATION", Review Gen. Elec., Paris, Vol. 55, pp. 103-108, March 1946.

The problem of wind power utilization is discussed, including determination of wind power per square meter obtained yearly from surfaces subjected to wind action, and systematic prospecting for favorable sites using a simple anemometric device which calculates wind speed with the aid of a special electric meter. A description is given of a program for site selection which will make it possible to determine the energy which can be produced by the wind engine used. (Technology Application Center, TAC, review)

3. Ailleret, P., "LA RECHERCHE DES SITES QUI POURRAIENT CONVENIR A UNE UTILISATION DE L'ENERGIE DU VENT", La Meteorologie, pp. 145-152, April-June, 1948.

To assess wind power possibilities, a wind energy survey is necessary. A wind energy meter developed for this purpose, the choice of site areas, and the first results of the survey are described. (TAC review)

4. Alaka, M.A., editor, "THE AIRFLOW OVER MOUNTAINS", Tech. Note N. 34, WMO-No. 98 TP.43, Secretariate of the World Meteorological Organization, Geneva, Switzerland, 1961.

5. Anderson, S.R., "A COMPARISON OF MONTHLY WIND MILEAGE FROM TYPE 45B AND U2A ANEMOMETERS", Department of Transport, Meteorological Office, Ottawa, Canada, 1956.

6. Andreyev, I.D., "WIND GUSTINESS WITHIN AN HOURLY INTERVAL", Voprosy Vetroenergetiki (questions of wind energy production), Moscow, an SSSR publication, 1959.

7. Anufriev, A.F., Supriaga, IA.A., "WIND ENERGY - ENERGETIC RESOURCES OF THE REPUBLIC KOMI, ASSR", Acad. of Sciences of the U.S.S.R., Filiale, Komi. Pp. 28-31, Moscow, 1963. 
8. Argand, "MEASUREMENT OF THE CHARACTERISTIC PARAMETERS OF WIIN POWER FOR THE SELECTION OF FAVOURABLE SITES FOR WINDDRIVEN GENERATORS", Proceedings of the U.N. Conference on New Sources of Energy, W/35, Rome, August 1961, Vol. 7, $\overline{\text { U.N.N. }}$ New York, 1964.

Time constants of Robinson, Papillon, and Ailleret anemometers considered as well as the Best-Romani type. Variation among these suggest that standards be established for presenting wind power data. World-wide wind power potential is discussed, a standard anemometer height above 20 meters is suggested, and projections with respect to the direction of wind power development in Europe and in developing countries are offered. (SB)

9. Aujesky, L., "COMPUTATION OF QUADRADIC AND CUBIC MEAN VALUES OF WIND VELOCITY FOR THE ESTIMATION OF AVAILABLE WIND POWER", Idojaras 55 (3/4): 79-81, March/April 1951.

Representations of wind conditions by average values of wind velocity are not sufficient to determine wind power at a given location. Theoretically wind power is proportional to the third power of wind and velocity. The usable power from sychonous generators is proportional to the square of the wind speed. Therefore it is necessary to compute quadratic and cubic means of wind velocity.

10. Ballester, Migue1, "SPECULATIVE METHODS IN WIND SURVEYING", Proceedings of the U.N. Conference on New Sources of Energy, W/7, Rome, August, $\overline{1961}, \overline{V o l .} \underline{7}, \bar{U} . \bar{N} .$, New York, $1 \overline{96} 4$.

Assumes the site can be selected and is not predetermined by the load center. Discusses field procedures and statistical procedure for comparing sites. Three sites in Spain were instrumented and statistically compared. The author suggests that site analysis is in its exploratory stage and that a mixture of subjective evaluation and rigorous scientific method must by necessity be used in site selection. ( $S B$ )

11. Barasoain, J.A. and Fontan, L., "PROSPECTING FOR WIND POWER WITH A VIEW TO ITS UTILIZATION", Proceedings of the U.N. Conference on New Sources of Energy, W/16, Rome, August, $\overline{1961}$, Vol. 7 , United Nations, New York, 1964.

This paper analyzes methods used in compiling, from the data furnished by meteorological services and the results obtained from specific wind prospecting networks, statistics for use in studies of wind power utilization. 
Pertinent results based on all available data are given in relationship to mainland Spain, and the most important wind basins are outlined and described. A general study of the winds prevailing in the region which embraces the Canary Islands and the coast-line of the Sahara desert is included and includes results from forty stations in this area and subsequent analyses of the wind. (SB)

12. Bergey, Karl H., "WIND POWER DEMONSTRATION AND SITING PROBLEMS", Wind Energy Conversion Systems, Workshop Proceedings, Washington, D.C., June, 1973, NSF/RA/W-73-006, pp. 41-45.

Technical and economic feasibility studies on a small windmill to provide overnight charging for an electrically driven car. Optimization of a windmill/storage system requires detailed wind velocity information which permits rational siting of wind power system stations. (TAC review)

13. Bettingnies, Christian, "POTENTIAL OF WIND POWER UTILIZATION IN THE ARCTIC ENVIRONMENT", Brace Research Institute, No. DT-10, 1970, McGill University, Montreal, Canada.

14. Briggs, J., "AIRFLOW AROUND A MODEL OF THE ROCK OF GIBRALTAR", Meteorological Office Scientific Paper No. 18, 1968.

15. Bitte, Jurgen and Frost, Walter, "ATMOSPHERIC FLOWS OVER A FENCE", report in preparation under NASA contract.

16. Blake, Stephen R., "SITE ANALYSES FOR LOCATING WIND ENERGY CONVERSION SYSTEMS", unpublished master's thesis, Department of Geography-Meteorology, University of Kansas, Lawrence, 1974 .

17. Blake, Stephen R. "INTERIM REPORT TO KARL J. BEA ASSOCIATES", Brace Research Institute, McGill University, Nov., 1974.

An exploratory site analysis for a fifty foot diameter wind turbine system proposed for Saskatchewan by Ultramar Oil Company of the United Kingdom. The report provides access to the workings of the Department of Transport, Meteorological Branch - Environment Canada and the procedures for accessing wind data from them. (SB) 
18. Blake, Stephen R., SITE ANALYSIS HANDBOOK FOR WIND ENERGY SYSTEMS, Appropriate Technology Group, Route 1, Box 93-A, Oskaloosa, Kansas, to be released in early 1977.

This handbook reviews the history of siting practices and synthesizes the information available today. Using this information as a starting point, procedures are offered for determining the optimum location for a family/small business size (less than 10 meter diameter) wind electric system in an area. Necessary equipment is described for measuring the power in the wind with examples provided for reference. Also considered are total system economics including system life, initial and recurring costs, present status of interfacing systems with power utility grids, maintainance schedules, and various methods for examining cost/benefits of a system. (SB)

19. Brevoort, M.J. and Jayner, U.T., "EXPERIMENTAL INVESTIGATIONS OF THE ROBINSON-TYPE CUP ANEMOMETER", Langley Memorial Aeronautical Laboratory, National Advisory Committee for Aeronautics, Langley Field, Va., October, 1934.

20. Buhl, S.M., "OPERATING EXPERIENCE OF WIND POWER PLANTS", World Power Conference, Belgrade, 1957, lith Sectional Meeting, Section B4, Paper 37, 11 pages, 1957.

In order to investigate the possibilities of producing electricity by means of wind power in connection with networks for the public supply, the Southeast Zealand Electricity Co. Ltd. (Called "SEAS" in Denmark) since 1947 has had wind energy measured in various places in Denmark, and after certain other preliminary investigations, a $12 \mathrm{KW}$ wind power plant has been erected. A second one, of $45 \mathrm{KW}$ was built in 1952. Since the end of 1953, both plants have been working regularly in connection with the SEAS network. An account is given of the daily, monthly, and annual outputs of the plants as well as of the way in which their output fits in with consumption of power from the SEAS network. This grid is normally supplied with energy from several thermal power plants in Zealand which are run in parallel with power stations in the southern part of Sweden. A third experimental wind power plant, of $200 \mathrm{KW}$ is being constructed in Denmark. (Review from Tech. Hag., Eindhoven, October, 1974).

21. Cambilargiu, "WIND MEASUREMENTS IN SOUTHERN ARGENTINA AND REMARKS ON WIND AND SOLAR ENERGY IN THAT COUNTRY", Proceedings of the U.N. Conference on New Sources of Energy, W/10, Vol.7, Rome, August, 1961, United Nations, New York, 1964. 
22. Casper, R.H., "VARIATIONS OF WIND VELOCITY IN GERMANY FOR WIND POWER GENERATION", ASCE translation 118: 463-488, 1953.

23. Changery, M., "INITIAL WIND ENERGY DATA ASSESSMENT STUDY", Second Workshop on WECS, June 9-11, 1975, 10.00, MITRE pp. 326-35.

This paper reports on the meterological data available from the National Climatic Center, Asheville, N.C. It discusses some of the problems in using this data to determine the siting of wind energy systems. Some suggestions are made on how to improve data acquisition methods by the use of uniform anemometer tower heights and the standardization of frequency of measurement. Figures included.

24. Christaller, H., "NUTZBARMACHUNG DE WINDENERGIE", Elektrizitaetswirtschaft 50 (11): 320-322, November 1951.

Translation: Linguistic Systems, Inc., Cambridge, Mass. N 74-16756, NTIS, Feb. 1974, 12 p.

25. Christaller, H., "INSTRUMENTS AVAILABLE IN GERMANY FOR MEASURING WIND POWER", from Windpower Working Party, Organization for European Economic Co-operation, pp. 189-193, printed by H.M.S.O., London, U.K., 1953.

26. Christaller, H., "WIND VELOCITY AND ECONOMIC ROTATIONAL SPEED OF WINDMILLS", Windpower Working Party, Organization for European Economic Co-operation, pp. 285-293, printed by H.M.S.O., London, U.K., 1953.

27. Cisman, A and N. V. Botan, "CONSIDERATIONS ON THE POSSIBILITY OF UTILIZING WIND ENERGY IN ROUMANIA", Rev. Stiint. 34: 35-42, January-June 1948. (In Roumanian)

Wind observations in the Balkans are recorded in order to show the possibility of installing wind turbines.

28. Cisman, A. and N. V. Botan, "SECOND PRELIMINARY REPORT ON THE POSSIBILITIES OF UTILIZING WIND ENERGY IN ROUMAINIA". Bull Inst. Rech. Tech Roumanie 3 (1): 95-99., 1948.

Continuation of previous study. 
29. Cormier, Rene V., "AN ANNOTATED LISTING - TALL TOWERS INSTRUMENTED FOR WIND OBSERVATIONS", Technical Report 73-0179, Air Force Cambridge Research Laboratory, L.G. Hanscom Field, Bedford, Mass., March, 1973.

30. Corotis, R.B., "STOCHASTIC MODELING OF SITE WIND CHARACTERISTICS", Second Workshop on WECS, June 9-11 1975, \$10.00, MITRE. pp. $341-43$.

An analytical approach consisting of a multidimensional stochastic model of wind characteristics involving spatial and temporal correlation.

31. Court, Dr. Arnold, "WIND SHEAR EXTREMES", a presentation appearing in Initial Wind Energy Data Assessment Study by

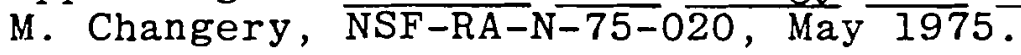

32. Crawford, K.C., Hudson, H.R., "BEHAVIOR OF WINDS IN THE LOWEST 1500 FEET IN CENTRAL OKLAHOMA", June 1966-May 1967, National Severe Storms Lab., Norman, Okla., 68 pp., August 1970.

Two towers are used in this test. Wind and temperature sensors are placed at different heights on the towers. Variability of wind speed and direction is investigated using transition matrices.

33. Cudbird, B.S.V., "DIURNAL AVERAGES OF WIND, ATMOSPHERIC PRESSURE, AND TEMPERATURE AT SELECTED CANADIAN STATIONS", Department of Transport, Meteorological Branch, Ottawa, Canada, Sept. 1964 .

34. Davenport, A.G., "RATIONALE FOR DETERMINING DESIGN WIND VELOCITIES", ASCE Proceedings (Structures Division), Vol. 86, 1960 .

35. Davenport, A.G., "THE SPECTRUM OF HORIZONTAL GUSTINESS NEAR THE GROUND IN HIGH WINDS", Quarterly Journal of Royal Meteorological Society, Vol. 87, No. 372, p. 194-211, 1961.

36. Davidson, Ben, "SITES FOR WIND POWER INSTALLATIONS", World Meteorological Organization Technical Note No. 63, Geneva, Switzerland, 1974 .

The most comprehensive overview of siting techniques and information available, Davidson considers all aspects 
of siting. The paper is aimed at large installations and assumes that the availability of wind power is the major factor in determining the location of a wind power installation. He concludes that sites must be analyzed individually and that no rules of thumb with respect to topographic influences on wind or to wind profiles may be applied out of hand. This paper synthesizes the work of other research and field work and is not based on the authors research in the field. (SB)

37. Deacon, E.L., "VERTICAL PROFILES OF MEAN WIND IN THE SURFACE LAYERS OF THE ATMOSPHERE", Geophysical Memoirs, Meteorological Office, London, 91, England.

38. Doraiswamy, I.V. and S.K. Banerji, "WIND DATA FOR WINDMILLS", India Meteorological Department, New Delhi, India, Scientific Notes VI (63): 1948 .

39. Duchon, Claude, "WIND VELOCITY AS MODIFIED BY GEOMORPHOLOGY, Second Annual Conference on WECS, June 9-11, 1975. pp. 367-371. MITRE. \$10.00.

40. Eldridge, Frank (editor), PROCEEDINGS OF THE SECOND WORKSHOP ON WIND ENERGY CONVERSION SYSTEMS, hel d in Washington, D.C., June 9-1 1,1975 , sponsored by NSF and ERDA, published by the Mitre Corporation, McLean, Va., 1975.

This broad based workshop brought together a broad range of individuals working in wind systems. Many of the presentations touch briefly on the siting of wind machines. Section VII of the workshop, "Wind Characteristics," includes these presentations: "WIND CLIMATOLOGY", by Jack W. Reed, Sandia Labs; "INITIAL WIND ENERGY DATA ASSESSMENT STUDY", by Michael Changery, NOAA/NCC; "WIND CHARACTERISTICS AND WIND POWER GENERATION: A THREE YEAR METEOROLOGICAL PROGRAM IN SWEDEN", by Lars OIsson, Olof Holme, and Roland Krieg, SAAB-SCANIA AB; "STOCHASTIC MODELLING OF SITE WIND CHARACTERISTICS", by Ross B. Corotis, Northwestern University; "SITES FOR WIND-POWER INSTALLATIONS" Robert N. Meroney, Colorado State University; "LOCATING AREAS OF HIGH WIND ENERGY POTENTIAL BY ERTS OBSERVATIONS OF AEOLIAN GEOMORPHOLOGY", by J. Marwitz and R. Marrs, University of Wyoming; "A NEW WIND ENERGY SITE SELECTION METHODOLOGY", by B.E. Freeman, Science Applications, Inc.; "ANNUAL POWER OUTPUT POTENTIAL FOR 100-KW AND L MW AEROGENERATORS" by C.G. Justus, Georgia Institute of Technology; "WIND VELOCITY AS MODIFIED BY GEOMORPHOLOGY", by Claude E. Duchon, University of Oklahoma; "A TECHNIQUE FOR OPTIMALLY LOCATING WIND ENERGY SYSTEMS" by 
Fred M. Vukovich and Andrew Clayton, Research Triangle Institute. These presentations are not reviewed herein as these workshop proceedings are currently a standard reference.

41. Frenkiel, J., "WIND FLOW OVER HILLS, IN RELATION TO WIND POWER UTILIZATION", Proceedings of the U.N. Conference on New Sources of Energy, W/33, Rome, August, 1961, United Nations, New York, 1964, Vol. $\underline{7}$.

Starting in 1953, Frenkiel undertook the study of wind power potential in Israel. He instrumented two types of peaks: 1) A mountain ridge athwart the prevailing wind direction with a steep leeward side; 2) An isolated peak in a valley in the general direction of prevailing winds. He concludes that criteria for a good wind power site emerges from his investigations, namely that the mean wind vertical gradient for the height interval from 10 to $40 \mathrm{~m}$ above the ground be I) less than five per cent for optimal sites 2 ) five to ten per cent for very good sites 3 ) ten to fifteen per cent for good sites 4) a mean power law exponent of no greater than .14 for fair sites. Further, he concludes that the slope of the hill determines this mean wind vertical gradient and relates to the above conditions as follows: 1) results from slopes of 1 in $3 \frac{1}{2} ; 2$ ) results from smooth, regular slopes of about 1 in 6; 3) results from smooth regular shallow slopes of about 1 in 10 , or fairly rough but regular slopes of about 1 in 6 ; 4) results from a variety of topographic conditions such as low-level coastal sites, smooth aerodynamically very shallow sloped of about 1 in 20 , very rough aerodynamically but regular steep slopes of about 1 in 6 , and very steep slopes with gradual slope gradient within a radius of about $50 \mathrm{~m}$ from the hilltop. These statements of Frenkiel's are rare in the literature of topographic effects on wind power sites. (SB)

42. Frenkiel, J., "WIND PROFILES OVER HILLS (IN RELATION TO WIND POWER UTILIZATION)", Quarterly Journal Royal Meteorological Society, Vol. 87, $196 \overline{1 .}$

This article is a condensed version of the presentation given at the U.N. Conference in Rome. (SB)

43. Frost, Walter, "REVIEW OF DATA AND PREDICTION TECHNIQUES FOR WIND PROFILES AROUND MANMADE SURFACE OBSTRUCTIONS", AGARG Conference Proceeding No. 140, Flight in Turbulence, Woburn Abbey, Bedfordshire, England, May 1973. 
44. Frost, Walter, "WIND FIELDS OVER TERRAIN IRREGULARITIES", a presentation in Initial Wind Energy Data Assessment Study, by M. Changry, NSF-RA-N-75-020, May 1975.

Considers wind flow with respect to flat terrain, various surface discontinuities, hills and mountains, valleys, and buildings. Numerous graphic images aid in explaining various phenomenon. (SB)

45. Garrison, J.A. and Cermak, J.E., "SAN BRUNO MOUNTAIN WIND INVESTIGATION - A WIND TUNNEL MODEL STUDY", Colorado State University, 1968 .

46. Gartsman, L.B., "PRINCIPLES FOR CALCULATING LIMITING VALUES OF ENERGY PRODUCING PARAMETERS OF THE WIND STRUCTURE", TASHKENT, IZD. An. Vz. SSR, 1963.

47. Geiger, Rudolf, THE CLIMATE NEAR THE GROUND, Harvard University Press, Cambridge, Massachusetts, $\overline{196} 5$.

48. Giblett, M.A., "THE STRUCTURE OF WIND OVER LEVEL COUNTRY", Geophys. Mem. Met. Off., London, Vol. 6, No. 54, 1932.

49. Gibson, LRA, "WIND ANALYSIS IN RELATION TO THE DEVELOPMENT OF WINDPOWER", Oklahcma State University, 147 pp. 1969.

50. Glann, H.R., "A METHOD FOR PREDICTING SURFACE WINDS", Weather Bureau, Silver Springs, Md., Systems Development Office, 21 pp., March 1970.

A method to operationally forecast surface winds. Several regression models are applied to available data. Indications are that this method produces short range forecasts of wind that are as accurate or more accurate than official aviation terminal forecasts.

51. Golding, E.W., and Stodhart, A.H., "THE POTENTIALITIES OF WINDPOWER FOR ELECTRICITY GENERATION", (with special reference to small scale operation), Electrical Research Association, Tech. Report WT 16, 26 pp., 1949.

52. Golding, E.W., "STUDIES OF WIND BEHAVIOR AND INVESTIGATION OF SUITABLE SITES FOR WIND DRIVEN PLANTS, NEW SOURCES OF ENERGY", Proceeding of UN Conference in Rome, Vol. $\underline{7}$ (gr/6w), pp. 3-8. 
53. Golding, E.W., "LARGE SCALE GENERATION OF ELECTRICITY BY WINDPOWER", Preliminary Report, Elect. Res. Assoc. Tech. Report c/T101, 1949.

Studies of winds at several sites in Great Britain.

54. Golding, E.W. and Stodhart, A.H., "THE SELECTION AND CHARACTERISTICS OF WIND POWER SITES", Electrical Research Association, Tech. Report C/T 108, $32 \mathrm{pp}$. , Leatherhead, Surrey, U.K., 1952 .

The methods used in and the results obtained from a wind survey in the United Kingdom are described in detail. (TAC review)

55. Golding, E.W., "MEASUREMENT OF WIND VELOCITY AND POWER", Windpower Working Party, Organization for European Economic Co-operation, printed by H.M.S.O., London, U.K., 1953, pp. 193-207.

56. Golding, E.W., THE GENERATION OF ELECTRICITY BY WIND POWER, Philosophical Library, Inc., New York, 1956.

57. Golding, E.W., "METHODS OF ASSESSING THE POTENTIALITIES OF WIND POWER ON DIFFERENT SCALES OF UTILIZATION", Solar and Aeolian Energy, Proceedings of the International Seminar held at Sounion, Greece, 1961, Plenum Press, New York, pp. $152-157$.

58. Griffith, H. L., Panofsky, H.A., and Van der Hoven, I., "POWER SPECTRUM ANALYSIS OVER LARGE RANGES OF FREQUENCY", Journal of Meteorology, Vol. 13, 1956, pp. 279-282.

59. Hagne, L.J. and Skidmore, E.L., "TURBULENT VELOCITY FLUCTUATIONS AND VERTICAL FLOW AS AFFECTED BY WINDBREAK POROSITY", Transactions of the ASAE, Vol. 14, No. 4, July-August, 1971.

60. Haldane, T.G.N., "THE LOCATION AND OPERATION OF WIND DRIVEN PLANT", Windpower Working Party, Organization for European Economic Co-operation, pp. 147-149, printed by H.M.S.O., London, U.K., 1953.

61. Harris, R.I., "ON THE SPECTRUM AND AUTO-CORRELATION FUNCTION OF GUSTINESS IN HIGH WINDS", Electrical Research Association Publication \#5273, Surrey, England, 1968. 
62. Heronemus, W.E., "POWER FROM THE OFFSHORE WINDS", Eighth Annual Conference and Exposition on Applications of Marine Technology to Human Needs, pp. 435-66, September 11-13, 1972.

63. Hewson, E.W., "WIND POWER POTENTIAL IN SELECTED AREAS OF OREGON", Report No. PUD 73-1, March 1973; No. PUD 74-2A, August 1974; No. PUD 74-2B, August 1974; No. PUD 75-3, August 1976; No. PUD 76-4, June 1976; Oregon State University, Department of Atmospheric Sciences.

The research which these reports describe was undertaken in 1971 by Oregon State University and four Oregon Peoples Utility Districts. Previous wind data was considered and new stations were established in locations of potentially high wind power. Various student projects were integrated into these reports including wind tunnel modeling and testing of landforms, and the use of smoke plume rockets for determining wind profiles. These studies are inspiring models for what individual states, utility companies, and universities can do in assessing wind power potential. (SB)

64. Heywood, G.S.P., "WIND STRUCTURE NEAR THE GROUND AND ITS RELATION TO TEMPERATURE GRADIENT", Quarterly Journal Royal Meteorological Society, Vol. 57, p. 433, 1931.

65. Hoff, W., "THEORY OF THE IDEAL WIND POWER MACHINE", Z Flugiechn. II : 223,1920 .

66. Huang, Chin-Hua and Nickerson, "STRATIFIED FLOW OVER NONUNIFORM SURFACE CONDITIONS: MIXING LENGTH MODEL", Journal of Boundry Layer Meteorology, January 1974.

67. Hutter, U., "THE USE OF WIND ENERGY FOR GENERATING ELECTRIC CURRENT IN WESTERN GERMANY", National Committee of the German Federal Republic, World Power Conference, Rio de Janeiro, 1954 (Titulo 4, Assunto 4.1).

68. Hutter, U., "PLANNING AND BALANCING OF ENERGY OF SMALLOUTPUT WIND POWER PLANT", Proceedings of the New Delhi Symposium on Wind and Solar Energy, UNESCO, Paris, 1956. 
69. Hutter, U., "THE EFFECT OF WIND FLUCTUATIONS ON THE CHOICE OF SPEED FOR WIND-POWER PLANTS", Zietschrift fur Elektrotechnik 1: $117-122,1948$ and 2: 10-15, 1949.

70. Hyson, P., "CUP ANEMOMETER RESPONSE TO FLUCTUATING WIND SPEEDS", Vo1. 2, No. 5, Journal of Applied Meteorology, pp. 843-848, Aügust 1972 .

71. Iyer, V.D., "WIND DATA FOR WINDMILLS". Ind. Met. Dep. Sci. Notes VI: 63, 1935.

72. Jensen, Martin, "WIND MEASUREMENTS", Proceedings of the U.N. Conference on New Sources of Energy, W/14, Rome, August 1961, Vol. 7, United Nations, New York, 1964.

This presentation describes wind velocity measurements made in Denmark, at the location of the Gedser windgenerator and at two other locations. A power distribution meter which describes the wind velocity in six intervals was used and is described. (SB)

73. Jespersen, Anders (editor), International Symposium on Molinology, Denmark, May 1969, Lyngby, Danske Mollers Venner, Brede Vaerk, 1971.

74. Justus, C.G., "WIND DATA COLLECTION AND ASSESSMENT" in Wind Energy Data Assessment Study, by M. Changery, NSF-RA-N-75-020, May 1975 .

75. Justus, C.G., "ANNUAL POWER OUTPUT POTENTIAL FOR $100 \mathrm{KW}$ AND 1 MW AEROGENERATORS", Second Annual Workshop on WECS, June 9-11 1975 , pp. 360-66.

This report presents 1 ) a method for computing actual expected output power from a wind generator given the observed wind speed distribution, 2) results of application of this method in the form of aerogenerator plant factor (ratio of average power output to rated power) for the Continental U.S. The plant factors that were evaluated have the characteristics of the NASA $100 \mathrm{KW}$ plumbrook machine and the design characteristics of the I MW aerogenerator. The Weibull was used because of its two parameters.

76. Juul, J., Supplement to the Report on the Results Achieved with SEAS Experiment Al Mill, Kanner (Leo)Associates, Redwood City California, 40 pp. 1974 
77. JuUl, J., "INVESTIGATION OF THE POSSIBILITIES OF UTILIZATION OF WIND POWER", Elektroteknikeren, Vol 45, pp. 607-635, Oct. 22, 1949 (available through the Electrical Research Association Leatherhead, Surrey, U.K., as translation IB1025).

Climatic conditions of Denmark are briefly surveyed and results of a series of measurements on wind velocity at different points and at different heights are tabulated with data on annual $\mathrm{kw}-\mathrm{hr}$ generation obtainable with various types of wind motor. The velocity-meter and motors are described. Annual variation of $\mathrm{kw}-\mathrm{hr}$ obtainable is shown in graphs. The economics of wind-power utilization are discussed in detail, with special regard to local conditions. (Review by Tech. Hag., Eindhoven)

78. Juul, J., "MEASURING WIND VELOCITIES AT VARYING HEIGHTS ABOVE GROUND", Windpower Working Party, Organization for European Economic Co-operation, printed by H.M.S.O., London, U.K., 1953.

79. Karmishin, A.V., "WIND AND ITS UTILIZATION", Moscow, Gos. IZD-VO Tekhniko Report, Litary, 1951, $62 \mathrm{p}$.

Discusses several characteristics of the wind.

80. Kleinhenz, F., "WEIGHT AND COST COMPARISON FOR LARGE WIND POWER PLANTS OF DIFFERENT HEIGHTS FOR THE SAME WHEEL DIAMETER", Stahibau No. 17/18: 1943.

81. Klevantsova, V.A., Bortkovskii, L., and Preobrahzenskii, L.Yu., "METHODS OF GRADIENT MEASUREMENT AT SEA", translated by A. Nurklik, Meteorological Translations, No. 14, pp. 55-66, Canada Department of Transport, Meteorological Branch, Ottawa, Canada, 1968.

82. Krasovskiy, N.V., "WIND ENERGY-PRODUCING RESOURCES OF THE USSR AND PROSPECTS FOR THEIR UTILIZATION". Atlas Energoresursou SSSR L. Moscow, Russia, Energoizolat Publications, 1936.

83. Lange, Karl O., "SOME ASPECTS OF SITE SELECTION FOR WIND POWER PLANTS ON MOUNTAINOUS TERRAIN", Proceedings of the U.N. Conference on New Sources of Energy, W/28, Rome, August 1961, Vol. 7, United Nations, New York, 1964.

Tradeoffs between height of tower and costs are considered. Speed-up of wind is desirable but not predictable from previous aerodynamic research. Subjective evaluations considered. (SB) 
84. Lantagne, Michel, "WIND POWER STUDY OF THE ST. LAWRENCE LOWLANDS, SURVEY OF AVAILABLE WIND DATA", Brace Research Institute, McGill University, Montreal, Quebec, Canada, Internal Report No. I-52, October 1968.

85. Lee, L., "SAMPLE RATE REQUIRED TO ESTIMATE ENERGY IN WIND SPEED RECORD". Unpublished Report, Oklahoma State University, 1967.

86. Lettau, H.H. and Davidson, Ben, EXPLORING THE ATMOSPHERE'S FIRST MILE, Volume 2 , Pergamom Press, New York, 201 pages.

87. Lumley, J.L. and Panofsky, THE STRUCTURE OF ATMOSPHERIC TURBULANCE, Interscience Publishers, New York, 1964, $231 \mathrm{pp}$.

88. Marwitz, J., and Marrs, R., "LOCATING AREAS OF HIGH WIND ENERGY POTENTIAL BY THE ERTS OBSERVATIONS OF AEOLIAN GEOMORPHOLOGY". Second Annual Workshop on WECS, June 9-11, 1975, $\$ 10.00$, MITRE. pp. 253-55.

This paper describes the research methods used to determine whether ERTS Observations can be used to locate favorable sites for WECS. The study is being conducted in the Great Basin of the Western U. S.

89. Masterson, G.E., "LABORATORY EXPERIMENTS ON THE TECHNIQUE OF SITE SELECTION USING AN ELECTROLYTIC TANK", Windpower Working Party, Organization for European Economic Co-operation, pp. 145-147, printed by H.M.S.O., London, U.K., 1953.

90. Meier, R.C., "CONCEPT ANALYSES OF LARGE WIND GENRATOR SYSTEMS", Paper presented at the 31 st Annual National Forum of the American Helicopter Society, Pre-print S-997, May 1977.

91. Merchant, D.A., STOCHASTIC MODEL OF WIND GUSTS, unpublished $\mathrm{Ph} . \mathrm{D}$. Thesis, Stanford University, 1965 .

92. Meroney, R.N. and Cermak, J.E., "WIND TUNNEL MODELING OF FLOW AND DIFFUSION OVER SAN NICOLAS ISLAND, CALIFORNIA", Colorado State University, 1967.

93. Meroney, R.N. and Chaudhry, F.H., "WIND TUNNEL SITE ANALYSIS OF DOW CHEMICAL FACILITY AT ROCKY FLATS, COLORADO", Colorado State University, 1972. 
100. Nilakantan, P., "SOME CONSIDERATIONS AFFECTING THE CHOICE OF AREAS FOR PRELIMINARY WIND POWER SURVEYS IN INDIA", from the Proceedings of the New Delhi Symposium on Wind and Solar Energy, UNESCO, paris, 1956, pp. 38-41.

101. Nilakantan, P. and Varadarajan, R., "STUDIES ON THE UTILIZATION OF WIND POWER IiN INDIA", Bangalore National Aeronautical Laboratory, Bangalore, India, 1962.

102. Oopt, A.H., Rasmusson, E.M., "ATMOSPHERIC CIRCULATION STATISTICS", Environmental Research Labs., Princeton, N.J. Geophysical Fluid Dynamics Lab., 335 pp. 1971.

103. Ower, E., THE MEASUREMENT OF AIRFLOW, Chapman and Hall, Ltd., 1949 .

104. Pagon, Watters, "WIND VELOCITY IN RELATION TO HEIGHT ABOVE GROUND", Engineering News-Record, Vol. 114, pp. 742-745, 1935.

105. Panofsky, H.A., "STATISTICAL PROPERTIES OF THE VERTICAL FLUX AND KINETIC ENERGY AT 100M.", Penna. State Min. Dev. Sci. Rep., No. 21, 1953.

106. Panofsky, r.A, and McCormick, R.A., "PROPERTIES OF SPECTRA OF ATMOSPHERIC TURBULANCE AT 100 METERS", Quart. Journal of Royal Met. Soc., Vol 80, 1954.

107. Perlat, "WIND MEASUREMENT IN METEOROLOGY", (summary), Proceedings of the U.N. Conference on New Sources of Energy, W/13, Rome, $\overline{\mathrm{V}} \mathrm{l} . \overline{7}$, August 1961, United Nations, New York, 1964.

The presentation indicates the way in which the wind is measured at meteorologicai stations and suggests standards for measurement procedures and equipment. (SB)

108. Peronaci, F., "DETERMINATION OF WIND ENERGY FOR THE PURPOSE OF ITS UTILIZATION BY WIND MACHINES", Annali di geofisica 3 (2): 223-230, April 1950.

The wind characteristics in several zones in Calabria are studied with wind machine installations in mind. 
94. Milakanton, P., "SOME CONSIDERATIONS AFFECTING THE CHOICE OF AREAS FOR PRELIMINARY WIND POWER SURVEYS IN INDIA, WIND AND SOLAR ENERGY", Proceedings of the New Delhi Symposium, UNESCO, Paris, pp. 38-41.

95. Monin, A.S. and Obukhov, A.M., BASIC LAWS OF TURBULENT MIXING IN THE GROUND LAYER OF THE ATMOSPHERE, translated from Akademiia Nauk, SSSRR, Leningrad, Geofizicheskii Institute, Trudy, Vol. 15l, No. 24, pp. 163-187, 1954 (reference from Aeroenvironment).

96. Morgans, W.R., "RELATION BETWEEN GROUND CONTOURS, ATMOSPHERIC TURBULANCE, WIND SPEED, AND DIRECTION", Aeronautical Research Committee Reports and Memoranda No. 1456 (T.3 198), December 1931 (reference from Brace Research Institue card catalogue, this is most likely a Canadian government publication).

97. Mullet, L.F., "SURVEYING FOR WIND POWER IN AUSTRALIA", Ins. Engineers, Australia - J, 29 (3): pp. 69-73, March 1957.

98. National Aeronautical Laboratory, Bangalore, India, series entitled "HOURLY WIND SPEEDS AT (the following cities) FROM THE POINT OF VIEW OF WIND POWER UTILIZATION":

Jamshedpur, No. TN-WP-34-64

Gopalpur, No. TN-WP-27-63

Allahabad, No. TN-WP-22-63

Bhopal, No. TN-WP-23-63

Calcutta (Dum Dum), No. TN-WP-28-63

Jaipur, No. TN-WP-25-68

Gaya, No. TN-WP-32-63

Amritsar, No. TN-WP-24-63

Ahmedabad, No. TN-WP-18-62
Kadaikanal, No. TN-WP-17-62 Vishakhapatnam No. TN-WP $-21-63$ Bombey (Santa Cruz) No. TN-WP-19-62

Jodhpur, No. TN-WP-29-63 Lucknow, No. TN-WP-26-63 New Delhi, No. TN-WP-3l-63 Poona, No. TN-WP-16-62

99. Nelson, Vaughn and Gilmore, Earl, "POTENTIAL FOR WIND GENERATED POWER IN TEXAS", State of Texas Governor's Energy Advisory Council, Report NT/8, October 1974.

This comprehensive report reviews the currently available hardware (1974), current research efforts, and the general context of wind energy. With this groundwork put forth, the wind data available from the National weather Service for Texas is analyzed and wind power potential for the state is derived. The panhandle of Texas is perhaps the area of the highest wind power potential in the country and this report is aimed at laying the groundwork for development of this resource within the state. A good model for other states. (SB) 
109. Petterssen, Sverre, "SOME ASPECTS OF WIND PROFILES", Proceedings of the U.N. Conference on New Sources of Energy, W/26,

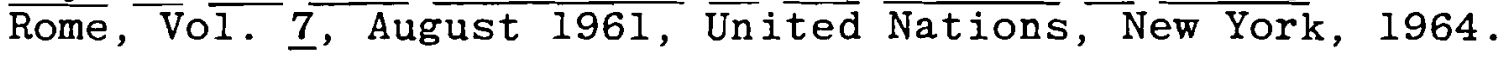

The profile descriptions of Prandtl, Deacon, Palm, Monin and Obukov, Ellison, and Swinbank are considered and Petterssen concludes that the models by Monin and Obukhov, Ellison, and Palm deserve particular attention for wind power sites. Present knowledge on sites on ridges is felt to be inadequate and little evidence indicates that speed-up factors exist over the mountains in new England from his work with the Smith-Putnam project. (SB)

110. Pigge, H., "ANNUAL AVAILABILITY AND SPEED CHARACTERISTICS OF THE WIND FOR WIND POWER UTILIZATION", Elektrizitatswirtschaft, Vol. 54, Oct. 1955, pp. 704-709.

Optimum design methods for wind driven electrical generating plants are presented, based on yearly permanent wind level lines for selected erection sites. Wind conditions at any site are divided by five classes, of which only a few can be exploited by a given system. General purpose design curves are given. (Review by TAC)

111. Plate, E.J. and Lin, Chi W., "THE VELOCITY FIELD DOWNSTREAM FROM A TWO-DIMENSIONAL MODEL HILL", Fluid Dynamics and Diffusion Lab, Colorado State University, 1965.

112. Prakasa Rao, M.S., Rada Krishnan, S.R., "A STUDY OF THE HOURLY WIND SPEEDS AT KODAKANAI FROM THE POINT OF VIEW OF WIND POWER UTILIZATION", National Aeronautical Lab., Bangalore (India) 24 pp., Dec. 1964.

113. Priestly, C.H.B., TURBULENT TRANSFER IN THE LOWER ATMOSPHERE, University of Chicago Press, 1959.

114. Putnam, P.C., POWER FROM THE WIND, Van Nostrand, Inc., New York, 1948 .

The classic work on the Grandpa Knob project. A detailed explanation of the assumptions and procedures used in siting the machine is given. It is determined that no a priori statements can be made with respect to speed-up over ridges from their experience. Correlations between limited data sets of wind velocity at several sites and wind velocities at nearby long established weather stations are considered. The machine produced from ten to thirty per cent of the power that had been anticipated from the 
site survey performed and it is concluded that had instruments been installed at the proposed site for sufficient time prior to machine installation, the particular site would not have been used. (SB)

115. Queney, P., "THE PROBLEM OF AIR FLOW OVER MOUNTAINS, A SUMMARY OF THEORETICAL STUDIES", Bull. Am. Met. Soc., Vol. 29, pp. 16-26, 1948.

116. Ramakrishnan, K.P. and Venkiteshwaran, S.P., "WIND POWER RESOURCES OF INDIA WITH PARTICULAR REFERENCE TO WIND DISTRIBUTION", Proceedings. of the U.N. Conference on New Sources of Energy, Vol. 7, W/19, Rome, August 1961, United Nations, New York, 1964.'.

Using wind run data from nearly 150 recording stations and hourly wind speeds for nearly 25 stations, the wind power potential of India is considered by the authors. Velocity duration curves of eight stations are derived. The use of water pumping equipment at a selected station is also included. (SB)

117. Ramdas, L.A., Rama Krishnan, K.P., "WIND ENERGY IN INDIA, WIND AND SOLAR ENERGY", Proceedings of the New Delhi Symposium, UNESCO, Paris, pp. 42-55, 1956.

118. Rangi, R.S., and Sout, P., Templin, R.J., "WIND POWER AND THE VERTICAL AXIS WIND TURBINE. DEVELOPED AT THE NATIONAL RESEARCH COUNCIL, CANADA", NRC, Division of Mechanical Engineering and National Aeronautical Establishment, Quarterly Bulletin, No. 2, pp. 1-14, 1974 .

119. Rao, D.V.L.N., Narasimhawswamy, K.N., Radhakrishnan, S.R., "A STUDY OF HOURLY WIND SPEEDS AT JAGDALPUR AND JAMSHEDPUR FROM THE POINT OF VIEW OF WIND POWER UTILIZATION", National Aeronautical Lab. Bangalore (India), 26 pp. Jan. 1964.

120. Rao, M.S.P., and Radhakrishnan, S.R., "VELOCITY MEASUREMENTS FOR CONVERTING WIND ENERGY TO POWER FOR WIND ELECTRIC GENERATOR OPERATION", National Aeronautics Lab., Tech. Note No. TN-WP-17-62, Bangalore, India, 1962 (NASA Accession No. N66-19213).

121. Reed, Jack, "WINDPOWER CLIMATOLOGY", Weatherwise, pp. 237-242, December 1974. 
122. Reed, Jack W., "WINDPOWER CLIMATOLOGY OF THE UNITED STATES", Sandia Labs, Albuquerque, N.M., SAND74-0348, June 1975

All suitable data in the National Climatic Center archives, for 758 stations, have been analysed for monthly, seasonal, and annual average wind power. Results have been assembled in maps with equal power (isodyn) contours to show geographic regions most suitable for wind power exploitation. An Appendix contains an almanac of all these wind speed distributions and power data tabulations, ordered by state and region and suitable for referencing.

Wind speed versus height above ground relationships were examined with upper air climatologies at $85 \mathrm{kPa}$ and $70 \mathrm{kPa}$ pressure-altitude levels and certain micrometeorological research towers. The one-seventh-law wind profile law appears adequate from this. (As abstracted by the publication) The stations presented are not described by anemometer heights and there has been no attempt to level the data to a standard anemometer height or to a standard atmospheric pressure. (SB)

123. Reed, Jack W., "ANEMOMETRY AND DATA PROCESSING" in Vertical Axis Wind Turbine Technology Workshop, May 17-20, $1 \overline{976,}$ Sandia Laboratories, Albequerque, N.M. , 1976.

124. Rosenbrock, H.H. and Tagg, J.R., "WIND AND GUST MEASURING INSTRUMENTS DEVELOPED FOR A WIND POWER SURVEY", Electrical Research Association, Leatherhead, Surrey, U.K., Publication No. C/T 104, 1951, $10 \mathrm{pp}$.

125. Rosenbrock, H.H., "THE DESIGN AND DEVELOPMENT OF THREE NEW TYPES OF GUST ANEMOMETER", Elect. Res. Associates Technical Report C/T106.1951. $37 \mathrm{pp}$.

126. Santorini, P., "A DIRECT METHOD OF MEASUREMENT AT WINDPOWER", Windpower Working Party, Organization for European Economic Co-operation, printed by H.M.S.O., Londson, U.K., 1953.

127. Sanuke, M., "WIND MEASUREMENT TECHNIQUES", Proceedings of the U.N. Conference on New Sources of Energy, Vol. $7, W / 2$. Rome, August 1961, United Nations, New York, 1964.

The errors in cup anemometers due to their nonlinearity of indication and the influence of atmospheric turbulence is discussed. Windmill anemometers not affected by turbulence are described and the over-estimation of wind 
speed by both cup and windmill type anemometers is considered. Site selection for wind measurement is considered as well as instrumentation technique.

The presentation is constructed to point up the difficulties in comparing wind data taken with different equipment and in changing equipment at an existing station. (SB)

128. Scorer, R.S., "MOUNTAIN-GAP WINDS: A STUDY OF SURFACE WIND AT GIBRALTER", Quarterly Journal of the Royal Meteorological Society, Vol. $7 \overline{8}$, No. 335, pp. 53-61, January $\overline{1952 .}$

129. Scorer, R.S., "AIRFLOW OVER AN ISOLATED HILL", Quart. J.Roy. Met. Soc., Vol 82, pp. 72-81, 1956.

130. Scrase, F.J., et.al., "THE ERRORS OF CUP ANEMOMETERS IN FLUCTUATING WINDS", Symposium of Papers on Electrical Meteorological Instruments, Session I, Journal Sci. Inst. Vol. 21, pp. 160-161, 1944 .

131. Sektorov, V.R., "THE PRESENT STATE OF PLANNING AND ERECTION OF LARGE EXPERIMENTAL WIND-POWER STATIONS", Elekrichestvo, No. 2, pp. 9-13, 1933. (Available through the Electrical Research Association, Leatherhead, Surrey, U.K., Translation No. IB 1064)

132. Serra, L., "NOTE ON THE UTILIZATION OF SMOKE PRODUCING ROCKETS FOR THE STUDY OF WIND", Tech. Paper No. 15, pp. 113-114, Wind Power Working Party, Organization of European Economic Co-operation, printed by H.M.S.O., London, U.K., 1953.

133. Serra, I., "LE VENT EN FRANCE ET SES POSSIBILITIES D'UTILIZATION", Meteorologie, pp. 273-292, 1953.

134. Shefter, Y.I., "SOME QUESTIONS IN DESIGNING AND CALCULATING FOR STRENGTH OF HIGH SPEED WIND MACHINES", Sbornik trudnov po zennledel cheskoy Mekhanike, (Handbook of Works of Farming Mechanics), Moscow - Leningrad, Sel'Khozgiz Publications, 1956.

135. Shefter, Y.I., "PRINCIPLES OF CALCULATION FOR OPTIMIZATION OF WIND MACHINE PARAMETERS", Mekhanizatsiya i electrifikatisiya sotsialisticheskogo sel' skogokhozyaystrva, (6), 1964.

136. Shellard, H.S., "EXTEME" WIND SPEEDS IN THE COMMONWEALTH OF THE CARIBBEAN", Caribbean Meteorological Institute, 1970. 
137. Sherlock, R.H., "VARIATIONS OF WIND VELOCITY AND GUSTS WITH HEIGHT", ASCE Transactions, Vol. 118, 1953.

Considers the flow of air in level, open country and concludes that the one-seventh-power law is a sufficiently close approximation to the variation of 5 minute wind velocity with height up to 1,000 feet above which a constant velocity is justified. Gust factors are proportional to the inverse ratio of heights raised to the power 0.0625 . (Abstract from the article.)

138. Shiotani, M., "DYNAMIC WIND PRESSURE ON STRUCTURE WITH REFERENCE TO TURBULENT PROPERTIES IN THE WIND NEAR THE GROUND", Railway Tech. Res. Rep. , Tokyo 4,2,1-4, June 1963.

139. Singer, Irving A. and Smith, Maynard E., "RELATION OF GUSTINESS TO OTHER METEOROLOGICAL PARAMETERS", Journal of Meteorology, Vol. 10, p. 122, April 1953.

Two years of data have been processed to show relationships between wind gustiness and other meteorological parameters. The gustiness classification used at Brookhaven National Laboratory is defined by the range and appearance of the horizontal wind direction trace. The seasonal and diurnal variations are presented. Gustiness is closely related to lapse rate and solar radiation, while its association with wind speed and Sutton's index of turbulence is not as distinct. (Abstract from the article.)

140. Sissenwine, N., Tattelman, P., Grantham, D., Gringorten, I., "EXTREME WIND SPEEDS, GUSTINESS AND VARIATIONS WITH HEIGHT FOR MIL-STD 210B", Air Force Cambridge Research Labs. (LKI), 29 August 1973. $72 \mathrm{pp}$.

141. Slade, D.H., "WIND MEASUREMENT ON A TALL TOWER IN ROUGH TERRAIN", Journal of Applied Meteorology, Vol. 8 , April 1969, pp. $293-297$.

This paper gives velocity versus height measurements on a TV tower in the Philadelphia area. The results show an increase in velocity of 100-200 per cent from 12 meters up to 270 meters above the hilltop. The paper also gives some turbulence factors and estimates the roughness height $Z$ to be from 2 to 3 depending on wind direction. (Review from Hewson, PUD 73-1) 
142. Sohn, Chang Wook, "WIND POWER PLANT SITE SELECTION", thesis in Mechanical Engineering, Texas Tech. University, May 1975.

A test of Putnam's ratio method using data from number of sites. Data from Reese Air Force Base and Lubbock, Texas is analysed ( 13 miles apart) and the error is found to be roughly 25 per cent. (Review from a conversation with Vaughn Nelson)

143. Soliman, K.H., "STUDY OF WIND BEHAVIOR AND INVESTIGATION OF SUITABLE SITES FOR WIND-DRIVEN PLANTS", Proceedings of U.N. Conference on New Sources of Energy, Vol. 7, W/4, Rome, August 1961, United Nations, 1964 .

A detailed study of the wind on the coast of Egypt looks at monthly and diurnal variations in wind velocities and concludes that four synoptic observations at six hour intervals provides a good indication of wind power potential.

(SB)

144. Stein, D.R., "THE COLLECTION AND EVALUATION OF STATISTICS ON ELECTRICITY GENERATION FROM WIND POWER STATIONS", Elektrizitatswirtschaft 50: 279-285, October 1951; 325-329, November 1951 . Translation: NTIS N 74-25618 1974, $23 \mathrm{p}$. and $\mathrm{N} 74-22708,16 \mathrm{p}$.

Detailed statistical evaluation of from 43-88 wind power plants in Denmark from 1941-1944. Plants are divided according to type and size. Comparison of actual and theoretical utilization of energy from the wind is discussed.

145. Stodhart, A.H., "THE GENERAL REQUIREMENTS OF SITES FOR WIND-DRIVEN GENERATORS" ${ }^{m}$, Windpower Working Party, Organization for European Economic Co-operation, pp. 181-185, printed by H.M.S.O., London, U.K., 1953.

146. Stodhart, A.H., "WIND DATA FOR WIND DRIVEN PLANT", Wind Energy Conversion Systems, Workshop Proceedings, Washington, D.C., June 11-13, 1973, NSF/RA/W-73-006, Dec. 1973.

147. Stodhart, A.H., "SELECTION OF TOWER HEIGHT FOR A WIND-DRIVEN PLANT", in Initial Wind Energy Data Study, by M. Changery, NSF-RA-N-75-020, May 1975, pp. $122-125$.

Stodhart considers tower height with respect to the exponent of the power law and offers parameters for evaluating these for self-supporting structures. Tower height 
is concluded to be a function of the cost/benefit ratio which in turn is directly influenced by the exponent. With exponents less than roughly.l, increasing tower heights is not beneficial financially. With exponents greater than .1 , tower height increases can be justified in certain conditions. (SB)

148. Stone, Thorp, "CLIMATOLOGY OF THE HANFORD AREA", Battelle Institute, BNWL-1604, June 1964

149. Sulzer, P., "A DIRECT METHOD FOR SELECTING WIND TURBINE GENERATOR; PARAMETERS FOR MAXIMUM ENERGY OUTPUT", Sulzer Associates, Stevensville, Md., 21666. 5 pp.

150. Sutton, O.G., "THE LOGARITHMIC LAW OF WIND STRUCTURE NEAR THE GROUND", Quart. J. Roy. Met. Soc., Vol. 63, pp. 105-107, London, 1937.

151. Syverson, Charles D. and Symons, John G., "INFORMATION AND PLANNING MANUAL FOR WIND DRIVEN ELECTRIC POWER SYSTERMS", Wind Power, Box 233, Mankato, Minn., 56001

An overview of wind systems aimed at persons considering the use of small scale installations. The siting information is vague, the economic discussion is excellent. (SB)

152. Tagg, J.R., "METHODS OF MEASUREMENT USED IN WIND VELOCITY SURVEYS", Tech. Paper No. 24, pp. 185-188, Wind Power Working Party, Organization for European Economic Co-operation, printed by H.M.S.O., London, U.K., 1953.

153. Tagg, J.R., "WIND DATA RELATEL TO THE GENERATION OF ELECTRICITY BY WIND POWER", Electrical Research Association, Tech. Report C/T 115, Surrey, England, 1957.

Purpose of this wind survey of Great Britain and Ireland was to assess potentialities of wind as sources of electrical energy; results of measurements analyzed; section dealing with results of wind measurements in other countries included to help in assessing potentialities of wind power overseas, and to compare different wind regimes. (TAC review) 
154. Tagg, J.R., "WIND MEASUREMENTS IN RELATION TO THE DEVELOPMENT OF WIND POWER", Proceedings of the U.N. Conference on New Sources of Energy, Vol. 7, w/12, Rome, August 1961, United Nations, New York, 1964.

The paper reviews the various types of anemometers and examines their suitability for different kinds of wind measurement. An outline scheme is given for the investigation of wind flow over an area. Comments are made on the installation of anemometers. The use which can be made of existing wind data is considered in relation to the wind measurements actually carried out. Two specially developed wind speed recorders are illustrated and described. A method is shown for comparing the value of one site with another in terms of specific output. Mention is made of several methods of recording extreme wind speeds for design purposes. (Tagg's summary of paper.)

155. Tattelman, Paul, and Gringorten, Irving, "ESTIMATED GLAZE ICE AND WIND LOADS AT THE EARTH'S SURFACE FOR THE CONTIGUOUS UNITED STATES", Technical report 73-0646, Air Force Cambridge Research Laboratory, L.G. Hanscom Field, Bedford, Mass., October 1973.

156. Taylor, C.C., "WINDMILLS FOR INDIA", American News File, Agricultural Supplement, March 2, 1949.

157. Technology Application Center,. WIND ENERGY UTILIZATION, A BIBLIOGRAPHY, University of New Mexico, Albuquerque, N.M., TAC W 75-700, 1975. Section 54,200, "SITING OF WINDMILLS".

158. Thuillier, R., and Lappe, V.O., "WIND AND TEMPERATURE PROFILE CHARACTERISTICS FROM OBSERVATIONS ON A 1400 FOOT TOWER", J. Appl. Met., Vol. $\underline{3}$, No. 3, 1964 .

159. United Nations, PROCEEDING OF THE UNITED NATIONS CONFERENCE ON NEW SOURCES OF ENERGY, Rome, August 21-31, 1961, Vol. 7: "WIND POWER", published by the United Nations, New York, 1964.

Presentations from this conference on siting for wind systems are listed and reviewed individually herein.

160. United Nations Educational, Scientiric, and Cultural Organization, WIND AND SOLAR ENERGY, proceedings of the New Delhi symposium, Paris, 1956 . 
161. Van der Hoven, I., "POWER SPECTRUM OF HORIZONTAL WIND SPEED IN THE FREQUENCY RANGE FROM 0.0007 to 900 CYCLES PER HOUR", Journal of Meteorology, Vol. 14, pp. 160-164, 1957.

162. Venters, J., "THE ORKNEY WINDMILL AND WIND POWER IN SCOTLAND", Engineer, Vol. 189, pp. 106-108, 1950.

Discusses the considerations and progress of research work which led to the choice of the site. The development of other sites in Scotland is probable. (Review from Tech. Hag. Eindhoven)

163. Vukovich, F.M. and Clayton, Andrew, "A TECHNIQUE FOR OPTIMALLY LOCATING WIND ENERGY SYSTEMS", Second Annual Conference on Wind Energy Systems, June 9-11, 1975, PP. 372-374. MITRE.

This paper discusses a proposed research project that will provide a technique for determining favorable windy locations. The study will be done in the St. Louis area but will be general enough to apply to other regions. A statistical model will be developed for relating wind speed and direction at each site to those at a synoptic weather station. Evaluation will be made by comparing the observed wind distributions to their corresponding predicted distributions.

164. Wallace, J.A., "AN ANNOTATED BIBLIOGRAPHY OF METEOROLOGICAL TOWER AND MAST STUDIES", Department of Commerce, Environmental Data Service, WB/BS-5, Jan. 1967, 110 pp., Washington, D.C.

165. Wax, M.P., "AN EXPERIMENTAL STUDY OF WIND STRUCTURE WITH REFERENCE TO THE DESIGN AND OPERATION OF WIND-DRIVEN GENERATORS", Electrical Research Association, Tech. Report C/T 114, Surrey, U.K., 1956 .

166. Wenk, F. "THE ANALYTICAL FORMULATION OF WIND SPEED FREQUENCEY CURVES", Windkraft-Mitt No. 5, 1970.

167. Wentink, Tunis $\mathrm{Jr}$., "SURFACE CHARACTERISTICS OF SOME ALEUTIAN ISLANDS", Wind Energy Conversion Systems, Workshop proceedings,

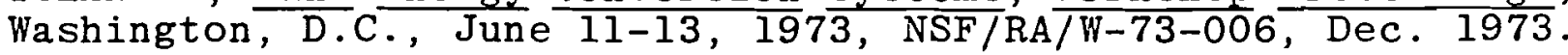


168. Wetherhold, Lyle (editor), PROCEEDINGS OF THE VERTICAL-AXIS WIND TURBINE TECHNOLOGY WORKSHOP, Albuquerque, New Mexico, May 18-20, 1976, Sandia Labs, 1976.

169. Wexler, R., "THEORY AND OBSERVATION OF LAND AND SEA BREEZES", Bull. Met. Soc., Vol. 27, pp. 272-287, 1946.

170. Wieringa, J., "GUST FACTORS OVER OPEN WATER AND BUILT-UP COUNTRY", Boundary-layer Meteorology, Vol. $\underline{3}$, pp. 424-441, 1973.

171. Windpower Working Party, PROCEEDINGS, Organization for European Economic Co-operation, printed by H.M.S.O., London, U.K., 1953 .

172. Witte, F., "THE POSITION OF WIND POWER UTILIZATION", Technik 2(11): 465-470, November 1947. (In German.)

A shortage of coal in Germany forces the use of wind power. This is a summary of wind characteristics in Germany and how a wind machine should be designed with these characteristics in mind.

173. World Meteorological Organization, "SURVEY OF EXISTING WIND OBSERVATIONAL INFORMATION", Proceedings of the United Nations Conference on New Sources of Energy, Vol. 7, Rome, August 1961, United Nations, New York, $196 \overline{4}$.

Review of the wind data available in the world. Concludes that existing wind observations are not always available in an ideal form for use in wind energy calculations. There is a trend seen for meteorological services to calculate. the frequency distribution of wind data instead of means. Data storage and retreival systems in computers are seen as major advances in this area.

174. Zbrozek, J.K., "ATMOSPHERIC GUSTS, PRESENT STATE OF THE ART AND FURTHER RESEARCH", Journal of the Royal Aeronautical Society, Vol. 69, pp. 27-45, Jan. 1965 . 


\section{ACKNOWLEGMENTS}

Acknowledgements and appreciation are due to the wind machine owners, distributors, and researchers who have provided us with their assistance. In particular, we would like to thank Ralph Schupbach, Robert Dodge, Larry Roach, Ed McCartle, Marcellus Jacobs, Claude Whitaker, George Suce, William Hughes, Claude Duchon, Vaughn Nelson, Jack Reed, Robert Meroney, and Allen $0^{\prime}$ Shea. It is more difficult to list the many others who, having an interest in the use of wind energy, provided us with the information that makes up the body of this report.

\section{PROJECT TEAM}

East Coast

Rick Katzenberg, Chris Pierson, Sheldon Fry, Herman Drees, Carolyn Drees

Midwest

Ben Wolff, Steve Blake

Rocky Mountains

John Saylor, Steve Blake

West Coast

Jack Park, Helen Park

Literature Review

Steve Blake, Carolyn Drees

Final Report

Ben Wolff, Jack Park, Herman Drees 


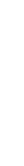


PIIL DISTRIBUTION

No. of

Copies

OFFSITE

\author{
A. A. Churm \\ DOE Chicago Patent Group \\ 9800 South Cass Avenue \\ Argonne, IL 60439
}

G. P. Tennyson

Department of Energy

600 E Street, N.W.

Washington, DC 20545

283
No. of

Copies

10

PNL

Report No.: BNWL-2220 WIND-9

Date:

December 1977

Ben Wolff

American Wind Energy Association c/o Windworks

P.0. Box 329, Route 3

Mukwonago, WI 53149

Richard Katzenberg

American Wind Energy Association

Natura1 Power Inc.

New Boston, NH 03070

E. J. Warchol

Bonneville Power Administration

P.0. Box 3621

Portland, OR 97225

S. J. Hightower

Bureau of Reclamation

Denver Federal Center

Bldg. 67 Code 254

Denver, CO 80225

Thomas Vonier

AIA Research Corp.

1735 New York Avenue, N.W.

Washington, DC 20006

Dr. Paul B. MacCready, Jr.

AeroVironment Inc.

145 Vista Avenue

Pasadena, CA 91107

Clarissa Quinlan

Alaska State Energy Office

M. Ginosar

California Solar Energy

Commission

Energy, Resources Conservation

\& Development Commission

1111 Howe Avenue, Mai1 Stop 15

Sacramento, CA 95825

Robert Ball

Center for the Environment \&

Man, Inc.

275 Windsor Street

338 Denali Street

Hartford, CT 06120

Dr. K. C. Spengler

American Meteorological Society

45 Beacon Street

Boston, MA 02108 
Dr. R. J. Hawks

Clarkson College

Potsdam, NY 13676

Dr. R. N. Meroney

Colorado State University

Fort Collins, CO 80523

E. H. Gilmore

Department of Agriculture

Agriculture Research Service

Bushland, TX 79012

L. A. Li1jedah 1

Department of Agriculture

Agriculture Wind Energy Program

Building 001 Room 126 BARC-West

Beltsville, MD 20705

Douglas $G$. Fox

Department of Agrculture

Forest and Mountain Meteorology

Rocky Mountain Forest and Range

Experiment Station

240 West Prospect St.

Fort Collins, CO 80521

Major T. E. Kullgran

Department of the Air Force

USAF Academy

CO 80840

Jay Tappan

Department of Energy

State of Oregon

Labor \& Industries Building

Room 111

Salem, OR 97310

Harry Moses

Department of Energy

Division of Biomedical \&

Environmental Research

Mail Stop E-201

Washington, DC 20545
Carl Miner TAN-604

EG\&G Idaho, Inc.

P.0. Box 1625

Idaho Falls, ID 83401

Dr. Edgar Demeo

Electric Power Research

Institute

3412 Hillview Avenue

Palo Alto, CA 94303

Jim Lerner

Energy Resources Conservation and Development Conmission

California Solar Energy Office

Mail Stop 15

Sacramento, CA 95825

Dr. W. Frost

FWG Associates, Inc.

R. R. 3 Box 331

Tullahoma, TN 37388

L. Krawitz

General Electric Company

P.0. Box 8555

Philadelphia, PA 19101

R. C. Koch

Geomet, Inc.

15 Firstfield Road

Gaithersburg, MD 20760

C. G. Justus

Georgia Institute of

Technology

Atlanta, GA 30332

Darryl Tompkins

JBF Scientific Corporation

1925 North Lynn Street

Suite 308

Arlington, VA 22209 
Dr. J. B. Knox

Lawrence Livermore Laboratory University of California

P.0. Box 808

Livermore, CA 94550

M. Abbey Page

Maine Office of Energy

Resources

55 Capito 1

Augusta, ME 04330

S. M. Howard

Meteorology Research, Inc.

P.0. Box 637

Altadena, CA 91001

Phillip French

NASA Scientific and Technical

Information Facility

P.0. Box 8757

Baltimore/Washington

International Airport

MD 21240

R. A. Wolf

NASA/Lewis Research Center

Mail Stop 500-201

Cleveland, $\mathrm{OH} 44135$

M. J. Changery

National Oceanic \& Atmospheric

Administration

National Climatic Center

Federal Building

Asheville, NC 28801

Ms. Peggy McDonald

N. E. Solar Energy Center

70 Memorial Drive

Cambridge, MA 02142

M. W. Edelstein

North American Weather

Consultants

600. Norman Firestone Road

Goleta, CA 93017
R. B. Corotis

Northwestern University

Evanston, IL 60201

E. W. Hewson

Oregon State University

Corvallis, OR 97331

S. C. Crow

Poseidon Research

11777 San Vicente Blvd.

Suite 641

Los Angeles, CA 90049

Dr. F. M. Vukovich

Research Triangle Institute

P.0. Box 12194

Research Triangle Park

NC 27709

Terry J. Healy

Rockwell International

Rocky Flats Plant

P.0. Box 464

Golden, C0 80401

2 R. E. Akins/J. W. Reed

Sandia Laboratories

Division 5443

P.0. Box 5800

Albuquerque, NM 87115

R. M. Traci

Science Applications, Inc.

P.0. Box 2351

La Jolla, CA 92038

D. M. Hardy

Solar Energy Research

Institute

1536 Cole Blvd.

Golden, CO 80401

Dr. C. M. Bhumralkar

Stanford Research

Institute, Int'1

Men lo Park, CA 94025 
PNL DISTRIBUTION

No. of

Copies
No. of

Copies

2

DOE Richland Operations Office
G. L. Liffick

H. E. Ransom

Dr. P. Yuen

University of Hawaii at Manoa

Holmes Ha11 240

54

2540 Dole Street

Honolulu, HI 96822

C. E. Duchon

University of $0 \mathrm{k}$ lahoma

200 Felgar Street

Norman, OK 73069

Dr. N. K. Wagner

University of Texas

Austin, TX 78712

Dr. M. Garstang

University of Virginia

Charlottesville, VA 22903

Dr. R. W. Marrs

University of Wyoming

Laramie, WY 82071

Ms. Susan Hosch

Washington State Energy Office

400 E. Union Ave. 1st. Floor

Olympia, WA 98504

Prof. Kent Rowe

Wichita State University

Box 444

Wichita, KS 67208

\section{Battel le-Northwest}

W. C. Cliff

R. L. Conley

J. C. Doran

R. L. Drake

C. E. Elderkin

R. K. Hadlock

M. M. Orgi11

W. T. Penne11

E. H. Phinney

J. V. Ramsde1 1

D. S. Renne

C. L. Simpson

L. L. Wende 11

Technical Information

Technical Publications
(5) 